\title{
Kyanite Formation and Element Fractionation in the High-Al Eclogites from the Sulu UHP Metamorphic Terrane
}

\author{
Yung-Hsin Liu ${ }^{1}$, Huai-Jen Yang ${ }^{1,}{ }^{*}$, Jianxin Zhang ${ }^{2}$, Yen-Hong Shau ${ }^{3}$, Mei-Fei Chu ${ }^{4}$, \\ Yoshiyuki Iizuka ${ }^{5}$, and Shu-Cheng $\mathrm{Yu}^{1}$ \\ ${ }^{1}$ Earth Dynamic System Research Center and Department of Earth Sciences, National Cheng-Kung University, Tainan 701, Taiwan, ROC \\ ${ }^{2}$ Institute of Geology, Chinese Academy of Geological Sciences, Beijing 100037, China \\ ${ }^{3}$ Department of Marine Biotechnology and Resources, National Sun Yat-Sen University, Kaohsiung 804, Taiwan, ROC \\ ${ }^{4}$ Department of Geosciences, National Taiwan University, Taipei 10617, Taiwan, ROC \\ ${ }^{5}$ Institute of Earth Sciences, Academia Sinica, Taipei 11529, Taiwan, ROC
}

Received 28 March 2009, accepted 12 June 2009

\begin{abstract}
Eclogite compositions are critical parameters for understanding chemical evolution in the Earth, particularly in subduction zones. A group of eclogites from the Sulu ultra-high pressure (UHP) metamorphic terrane in eastern China shows uncommon petrographic and compositional features. They are characterized by (1) zoisite porphyroblasts coexisting with inclusion-free, inclusion-containing, and network kyanite, (2) high $\mathrm{Al}_{2} \mathrm{O}_{3}$ of $18.4-29.2 \%$ with high $\mathrm{MgO}$ of $8.59-11.3 \%$, and (3) intensive HFSE-REE fractionations represented by $[\mathrm{Zr} / \mathrm{Sm}]_{\mathrm{ch}}$ and $[\mathrm{Ti} / \mathrm{Gd}]_{\mathrm{ch}}$ ratios of $0.1-3.9$ and $1.1-9.0$, respectively. High-pressure fluids played a major role on developing these features. Kyanite shows two textural varieties. $\mathrm{Ky}_{\mathrm{I}}$ is inclusion-free and in apparent textural equilibrium with garnet and omphacite, implying formation from plagioclase breakdown. $\mathrm{Ky}_{\mathrm{II}}$ includes kyanite networks and porphyroblasts; the former occurs mostly in garnet, whereas the latter encloses garnet and omphacite grains. $\mathrm{Ky}_{\mathrm{II}}$ were crystallized at the expense of garnet and omphacite during eclogite-fluid interaction. The low [HREE $]_{\mathrm{ch}}$ ratios of 1 - 2 indicate that the protoliths were arc cumulates. The well-defined inverse $\mathrm{Al}_{2} \mathrm{O}_{3}-\mathrm{SiO}_{2}$ and $\mathrm{Al}_{2} \mathrm{O}_{3}-\mathrm{CaO}$ correlations are not the characteristics of igneous precursors; therefore, must reflect metamorphic modifications. The comparison to mafic cumulates shows that the low-Al samples are compositionally better representatives of protoliths. Mass balance calculations point to an olivine gabbronoritic protolith. The intensive HFSE-REE fractionations reflect compositional differences between two sample groups. Group I samples have superchondritic HFSE-REE ratios [(Nb/La, $\left.\mathrm{Zr} / \mathrm{Sm}, \mathrm{Ti} / \mathrm{Gd})_{\mathrm{ch}}=2-7\right]$ with depletions in LREE. In contrast, group II samples show HFSE depletions and LREE enrichments. These compositional differences were explained as reflecting element mobility during eclogite-fluid interaction. Released at temperatures $>750^{\circ} \mathrm{C}$, the high-pressure fluids were enriched in HFSE, REE, and LILE. Upon migration, the fluids first precipitated HFSE into the group I samples, then, LILE and LREE into the group II samples. This model is supported by the occurrence of zoisite porphyroblasts in the group II samples, and interstitial zircon and clusters of small rutile grains along annealed fractures in the group I samples. Our interpretation for the observed compositional variations implies limited element mobility during subduction and exhumation of continental lithosphere, consistent with existing models, which proposed that the chemical flux to metasomatized mantle wedge is mainly from subducted sediments.
\end{abstract}

Key words: HFSE-REE fractionation, HFSE enrichment, Eclogite-fluid interaction, Eclogite, Sulu UHP metamorphism

Citation: Liu, Y. H., H. J. Yang, J. Zhang, Y. H. Shau, M. F. Chu, Y. Iizuka, and S. C. Yu, 2010: Kyanite formation and element fractionation in the high-Al eclogites from the Sulu UHP metamorphic terrane. Terr. Atmos. Ocean. Sci., 21, 277-298, doi: 10.3319/TAO.2009.06.12.01(TT)

\section{INTRODUCTION}

Models for mass transfer in subduction zones are mainly built upon element fractionations in subducted materials and

\footnotetext{
* Corresponding author

E-mail:hjyang@mail.ncku.edu.tw
}

erupted arc lavas. Compared to that of arc lavas, compositions of eclogites are diverse, providing critical information for comprehending subduction zone processes (e.g., Spandler et al. 2003; John et al. 2004). Various extents of element fractionation have been documented from the 
compositions of eclogites having an oceanic affinity. The compositional similarities between the Alpine eclogites and their precursors led Chalot-Prat et al. (2003) and Miller et al. (2007) to conclude isochemical metamorphism during subduction and exhumation of the Tethys lithosphere. In contrast, using a database compiled from the Alpine, Münchberg, and Variscan eclogites, Becker et al. (2000) argued that subducted altered oceanic crust can lost $>95 \%$ $\mathrm{K}$ and $\mathrm{Ba}$ with $<10-20 \%$ decreases in the abundances of high-field strength elements (HFSE), Th, Nd, Sm, and heavy-rare-earth elements (HREE). Some Zambia eclogites, however, have $\mathrm{Zr} / \mathrm{Sm}$ and $\mathrm{Nb} / \mathrm{La}$ ratios higher than their MORB-like protoliths, reflecting relatively intensive light-REE (LREE) and middle-REE (MREE) removal by fluids without changes on the HFSE budgets during subduction (John et al. 2004). In contrast to the immobile behavior of HFSE in most eclogite suites, the occurrence of rutile and zircon in an eclogite-facies vein from the Western Alps indicates that HFSE can be mobile in the eclogite stability field (Rubatto and Hermann 2003). The absence of zircon from the rutile-enriched veins and segregations in the Tianshan subudction complex (mainly blueschists and eclogites) provides evidence for $\mathrm{Zr}$ and $\mathrm{Hf}$ decoupled from $\mathrm{Ti}, \mathrm{Nb}$, and $\mathrm{Ta}$ (Gao et al. 2007). These results lead to a general mobility order of LILE (large-ion lithophile elements) $>$ LREE $>$ MREE $>$ HFSE $>$ HREE for the formation of eclogites having an oceanic affinity. The difference in element mobility reflects metamorphic pressure-temperature (P-T) conditions and the amount of fluid that interacted with eclogites (e.g., Hermann et al. 2006; Gao et al. 2007).

In contrast to the prosperous database for eclogites having an oceanic affinity, element fractionation during subduction and exhumation of continental crust has not been as intensively investigated. Metamorphosed at ultra-high pressures (UHP), eclogites from the Dabie-Sulu metamorphic terrane in eastern China have drawn much attention in the last decade. While most studies focused on the continental nature of protoliths (Jahn 1998, 1999; Zheng et al. 2003) and mineral characteristics at the UHP conditions (e.g., Zhang et al. 1995; Hwang et al. 2000; Ye et al. 2000), Liu et al. (2007) reported a prominent compositional feature from the high $\mathrm{Fe}$-Ti eclogites in the Sulu terrane. That is the Ti-enrichment accompanied by depletions of other HFSE (Nb, Ta, Zr, and Hf). Based on mass balance calculations, they concluded that such a decoupling between HFSE reflects protolith characteristics. In contrast, Zhao et al. (2007) emphasized that the andesitic compositions of some eclogites and amphibolites recovered from the Chinese Continental Scientific Drilling (CCSD) project were resulted from metamorphic modifications. They also proposed that the phengite-free eclogites with strong depletions in LREE and LILE were residues after melt extraction. Although significant amounts of water were also released during UHP metamorphism (e.g., Chen et al. 2007; Zhang et al. 2008), little is known about the chemical impacts of high-pressure fluids on eclogites with a continental affinity, hindering a thorough understanding on element cycling within the interior of the Earth.

In this contribution, we present unusually high $\mathrm{Al}_{2} \mathrm{O}_{3}$ concentrations and intensive REE-HFSE fractionations from a subgroup of kyanite eclogites collected near the CCSD site. Based on petrographic textures, mass balance calculations and comparisons to igneous precursors, we show that these compositional features were resulted from interacting with high-pressure fluids. We also suggest that the observed element fractionations occurred in a limited scale; therefore, did not contribute significantly to the element fractionations in subduction zone lavas.

\section{GEOLOGICAL SETTING AND SAMPLES}

The Dabie-Sulu orogenic belt in east-central China is a surface manifestation from collision between the SinoKorean and Yangtze cratons (Fig. 1). The eastern Sulu terrane is offset $\sim 530 \mathrm{~km}$ to the north of the western Dabie terrane by the NE-trending Tanlu fault on the west. Bounded by the Wulian-Qingdao-Yantai fault (WQYF) on the northwest and the Jiashan-Xianshui fault (JXF) on the southeast, the Sulu terrane has been divided into northern UHP and southern high-pressure (HP) metamorphic zones (Zhang et al. 1995; Fig. 1). In the UHP zone, eclogites and serpentinized peridotites occur as layers and blocks in gneisses and schists or as "boudins" and nodules in marbles (e.g., Zhang et al. 1995). These metamorphic rocks are overlain by Jurassic sedimentary and Cretaceous volcanoclastic successions, which were intruded by post-orogenic Mesozoic granites. Protoliths of the metamorphic lithologies are Neoproterozoic with subordinate amounts of Paleoproterozoic-Archean relicts (summarized by Zheng et al. 2003). The occurrence of coesite in eclogites, ultramafic rocks, and country gneisses is indicative of UHP metamorphism (e.g., Hirajima et al. 1990; Liou and Zhang 1996; Kato et al. 1997). Equilibrium P-T calculations and geochronological studies on these metamorphic lithologies concluded peak metamorphism at 680 $890^{\circ} \mathrm{C}$ and $28-44 \mathrm{~kb}$ (Zhang et al. 1995, 2006) during 210 $230 \mathrm{Ma}$ (e.g., Li et al. 1993, 2000; Ames et al. 1996) followed by amphibolite facies retrogression at $180-200 \mathrm{Ma}$ (e.g., Chavagnac and Jahn 1996; Li et al. 2000). The HP belt consists of quartz-mica schists, marbles and rare blueschists. They have not been intensively investigated due to scarce outcrops. Eclogite samples were excavated from a quartz crystal mining pit, which was $\sim 5 \mathrm{~m}$ deep with a surface area of $\sim 20 \mathrm{~m}^{2}$ and was located $\sim 1 \mathrm{~km}$ southeast of the CCSD site. The spatial relationships of these samples are uncertain because of the lack of exposed outcrops.

\section{PETROGRAPHIC DESCRIPTIONS}

The eclogite samples are composed mainly of garnet 


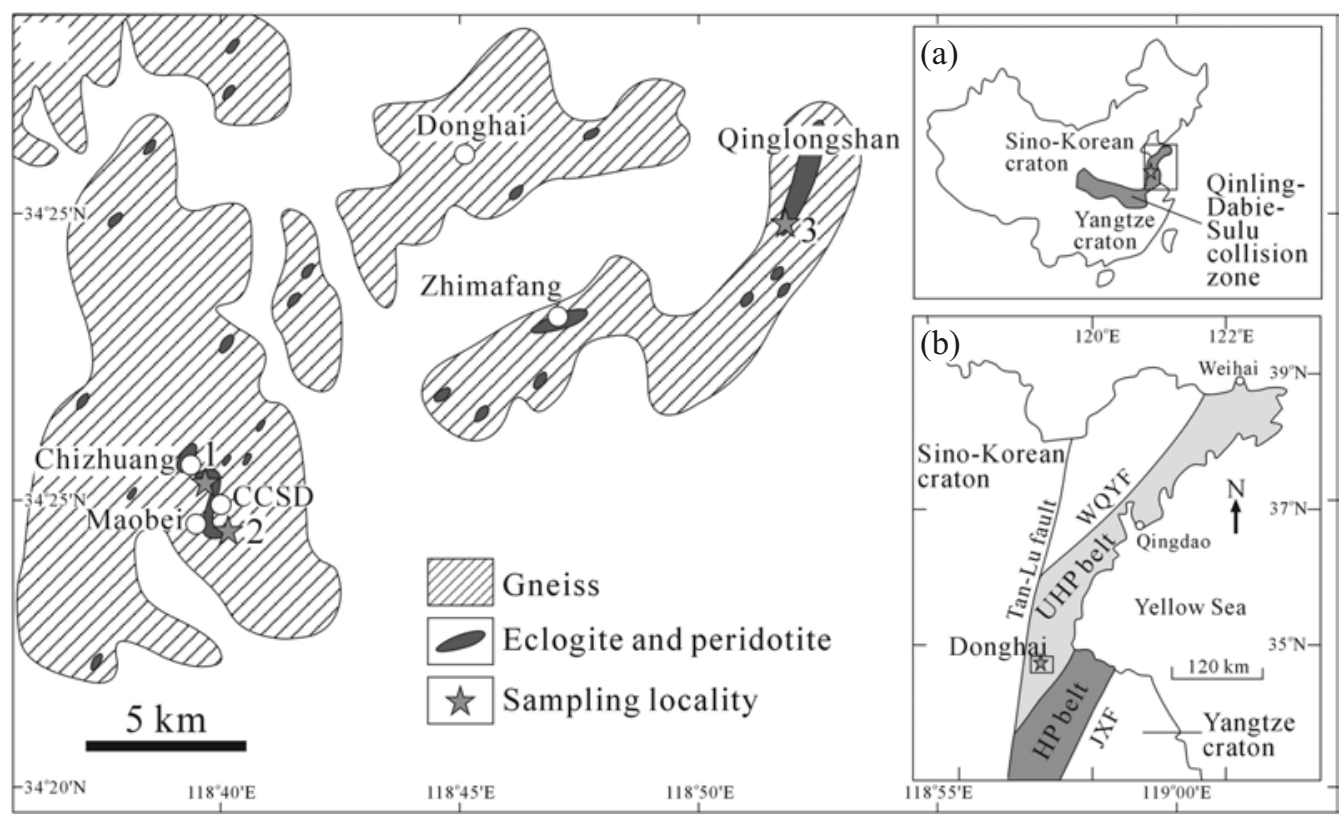

Fig. 1. A simplified geological map for the rectangle area in the lower insert showing the eclogite outcrops near the Donghai County in the Sulu metamorphic terrane. The star indicates sampling locality, which is $\sim 1 \mathrm{~km}$ southeast of the CCSD drilling site $\left(34^{\circ} 25^{\prime} \mathrm{N}, 118^{\circ} 40^{\prime} \mathrm{E}\right)$. The upper inset shows the Qinling-Dabie-Sulu collision zone located at east-central China with a rectangle enclosing the Sulu terrane, which is bounded by the Wulian-Qingdao-Yantai fault (WQYF), Jiashan-Xianshui fault (JXF) and Tanlu fault. The area in the rectangular is enlarged at the lower insert, which illustrates the UHP and HP metamorphic belts in the Sulu metamorphic terrane.

and omphacite with diverse proportions of phengite, kyanite, zoisite, rutile, and zircon. On hand specimen and thin section scales, seven of the nine eclogite samples show banded texture of alternating $0.5-5 \mathrm{~mm}$ garnet-rich and omphacite-rich layers (Fig. 2a). Garnet and omphacite occur as anhedral to subhedral grains or as inclusions in kyanite, zoisite, or phengite porphyroblasts $(>6 \mathrm{~mm})$. Without the banded texture, samples MB004 and 0724 are characterized by aggregates and porphyroblasts of garnet and omphacite. Kyanite proportion varies in a large range of $1-24 \mathrm{vol} \%$ (Table 1). Zoisite is rare in samples MB004, MB006, MB99-2, and $0724(\leq 0.2 \%)$, but common in other five samples (4 20 vol\%; Table 1). Other accessory minerals include phengite, rutile, zircon, and retrogression phases, such as amphibole, plagioclase, and epidote. Quartz only occurs as a minor phase in amphibolitic veins.

The samples are distinct from most Sulu eclogites for containing significant amounts of kyanite. The kyanite grains are classified into two textural groups. $\mathrm{Ky}_{\mathrm{I}}$ is inclusion-free, anhedral, texturally in equilibrium with garnet and omphacite (Fig. 2b), and usually $<3 \mathrm{~mm}$. Another group of kyanite initially crystallized along the grain boundaries and fractures within garnet and, in rare case, omphacite, forming irregular networks as described in Zhang et al. (1995) (Fig. 2c). Continuous crystallization of such an irregular network could form kyanite porphyroblasts of up to $9 \mathrm{~mm}$, enclosing garnet, subordinate amounts of omphacite, and rare rutile grains (Fig. 2d). The irregular network and inclusion-containing kyanite are referred to as $\mathrm{Ky}_{\mathrm{II}}$, which apparently crystallized at the expense of garnet, omphacite, and rutile.

Zoisite generally occurs as subhedral elongated porphyroblasts aligned along garnet-omphacite layers. They usually contain garnet, omphacite, phengite, and $\mathrm{Ky}_{\mathrm{I}}$ inclusions (Fig. 2e). Some zoisite grains show network texture similar to that of $\mathrm{Ky}_{\mathrm{II}}$.

Most phengite grains $(<1.8 \mathrm{~mm})$ are in textural equilibrium with garnet, omphacite, and $\mathrm{Ky}_{\mathrm{I}}$ (Fig. 2b). Few phengite grains occur as inclusions in garnet, omphacite, zoisite, and amphibole. Muscovite and biotite only occur in the amphibolitic veins and symplectites. In samples MB99-1, MB99-3, and MB99-4, phengite porphyroblasts (>3 mm) contain garnet, omphacite, and rutile inclusions.

Rutile grains of $0.05-0.7 \mathrm{~mm}$ in diameter are texturally in equilibrium with garnet and omphacite. Clusters of smaller rutile inclusions $(10-50 \mu \mathrm{m}$, mostly $<20 \mu \mathrm{m})$ occur along annealed fractures or veins in garnet and omphacite (Fig. 2f). They are common in samples MB004, MB006, and 0724, and less abundant in sample MB99-2, but rare in other samples. Zircon $(\sim 35 \mu \mathrm{m})$ with garnet and omphacite inclusions occurs as interstitial grains or near fractures within garnet and omphacite.

Based on these petrographic textures, it is inferred that garnet, omphacite, phengite, and $\mathrm{Ky}_{\mathrm{I}}$ were equilibrated at peak metamorphism. $\mathrm{Ky}_{\mathrm{II}}$, zoisite, and probably some phengite crystallized during early retrogression. Symplectites and veins formed when the eclogites exhumed to shallower le- 

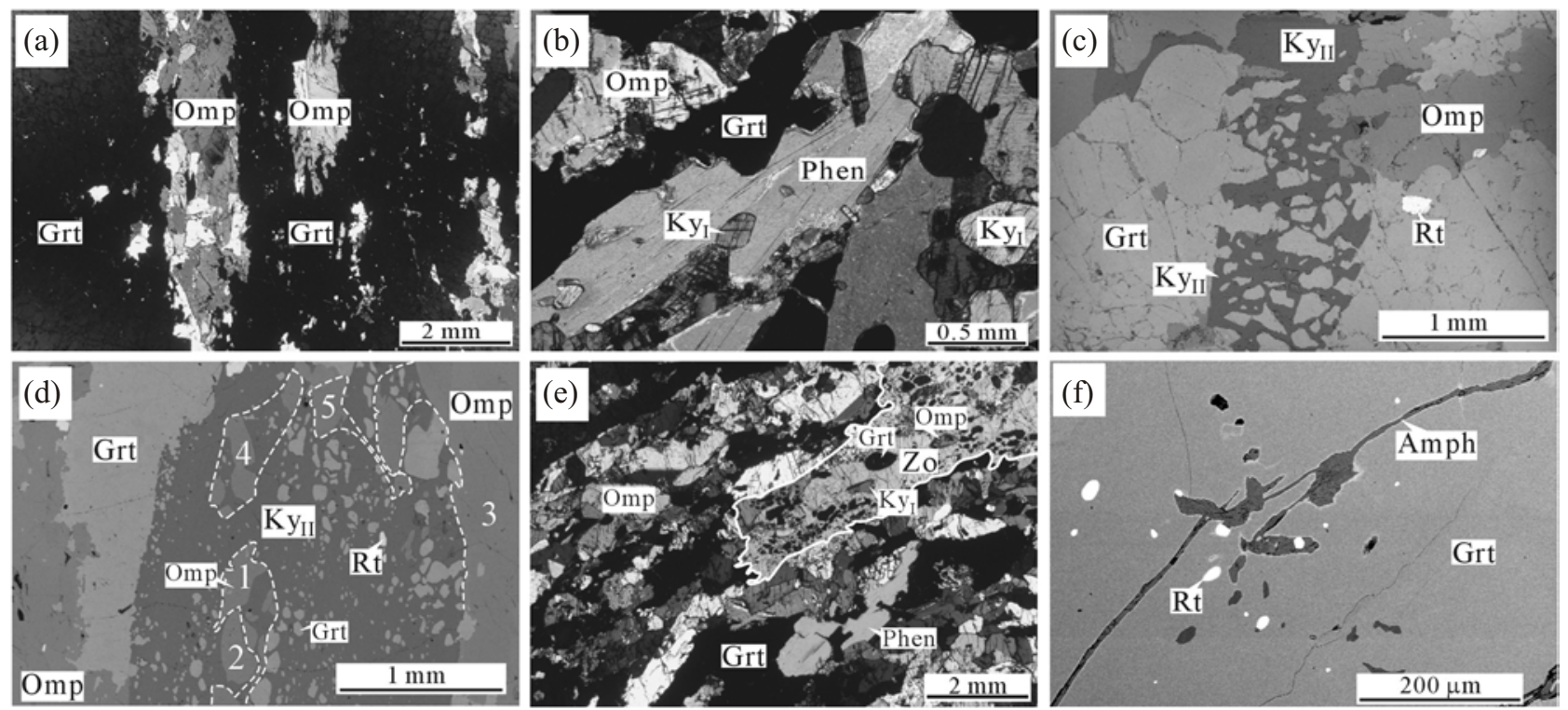

Fig. 2. Photomicrographs (a), (b), (e) and SEM BSE images (c), (d), (f). (a) Alternating garnet-rich and omphacite-rich layers reflecting metamorphic differentiation (sample MB99-2; crossed polars). (b) Peak metamorphic assemblage represented by the coexistence of garnet (Grt), omphacite (Omp), phengite (Phen), and kyanite ( $\left.\mathrm{Ky}_{\mathrm{I}}\right)$ (sample MB99-1; crossed polars). (c) Irregular kyanite network (Ky $\mathrm{K}_{\mathrm{II}}$ ) crystallized along fractures within garnet, indicating crystallization after garnet (sample MB99-3). (d) A kyanite porphyroblast $\left(\mathrm{Ky}_{\mathrm{II}}\right)$ containing garnet, omphacite, and rutile inclusions (sample MB006). The numbers label omphacite inclusions and grains of same extinction angles. (e) An elongated zoisite porphyroblast (Zo) with Ky $\mathrm{I}_{\mathrm{I}}$, garnet, and omphacite inclusions (sample MB99-1; crossed polars). (f) A cluster of small rutile inclusions (10 - $50 \mu \mathrm{m}$, mostly $<20 \mu \mathrm{m})$ crystallized along annealed fractures and veins in a garnet grain (sample MB004).

Table 1. Mineral assemblages and proportions (vol\%) in the high-Al eclogite samples from the Sulu UHP metamorphic terrane.

\begin{tabular}{|c|c|c|c|c|c|c|c|c|c|}
\hline Sample & MB004 & MB006 & MB99-2 & 0724 & 0729 & MB007 & MB99-1 & MB99-3 & MB99-4 \\
\hline Garnet & $45.6^{\mathrm{a}}$ & 31.3 & 73.4 & 39.0 & 39.9 & 30.8 & 36.1 & 47.0 & 50.9 \\
\hline Omphacite & 47.1 & 61.5 & 21.8 & 49.9 & 30.0 & 35.2 & 36.9 & 28.8 & 28.1 \\
\hline $\mathrm{Ky}_{\mathrm{I}}^{\mathrm{b}}$ & 0.2 & 1.0 & 1.0 & 0.5 & 1.8 & 8.1 & 7.9 & 1.8 & 6.1 \\
\hline $\mathrm{Ky}_{\mathrm{II}}^{\mathrm{b}}$ & 1.0 & 5.2 & 2.7 & 7.4 & 22.1 & 3.8 & 9.7 & 0.7 & 1.3 \\
\hline Zoisite & 0.1 & $\operatorname{tr}^{\mathrm{c}}$ & 0.2 & tr. & 4.4 & 20.3 & 8.1 & 10.9 & 7.6 \\
\hline Phengite & tr. & 0.2 & 0.1 & tr. & tr. & 1.1 & 0.7 & 2.4 & 5.6 \\
\hline Rutile & 0.4 & 0.3 & 0.1 & 0.6 & 0.2 & 0.2 & 0.1 & 1.1 & 0.4 \\
\hline Others $^{\mathrm{d}}$ & 5.6 & 0.5 & 0.7 & 2.6 & 1.6 & 0.5 & 0.5 & 7.3 & tr. \\
\hline $\mathrm{Grt} / \mathrm{Omp}^{\mathrm{e}}$ & 0.97 & 0.51 & 3.37 & 0.78 & 1.33 & 0.88 & 0.98 & 1.63 & 1.81 \\
\hline
\end{tabular}

Note: ${ }^{a}$ Mineral proportions were determined by $1900 \sim 3000$ point counts.

${ }^{b}$ See text for descriptions on the petrographic textures of $K y_{I}$ and $K y_{I l}$.

c "tr." indicates present but $<0.1$ vol\%.

${ }^{d}$ Symplectites and vein minerals.

${ }^{e}$ Volume ratio of garnet/omphacite.

vels. The proportions of veins and symplectites are $<3 \mathrm{vol} \%$ (Table 1), except for samples MB99-3 (7.3 vol\%) and MB004 (5.6 vol\%). Therefore, the compositions of these eclogites were not significantly modified during exhumation to shallower levels.

\section{ANALYTICAL METHODS}

Mineral compositions (Table 2) were determined by electron microprobe with wavelength dispersive spectrometers (WDS; JEOL JXA-8900R) at the Institute of Earth 


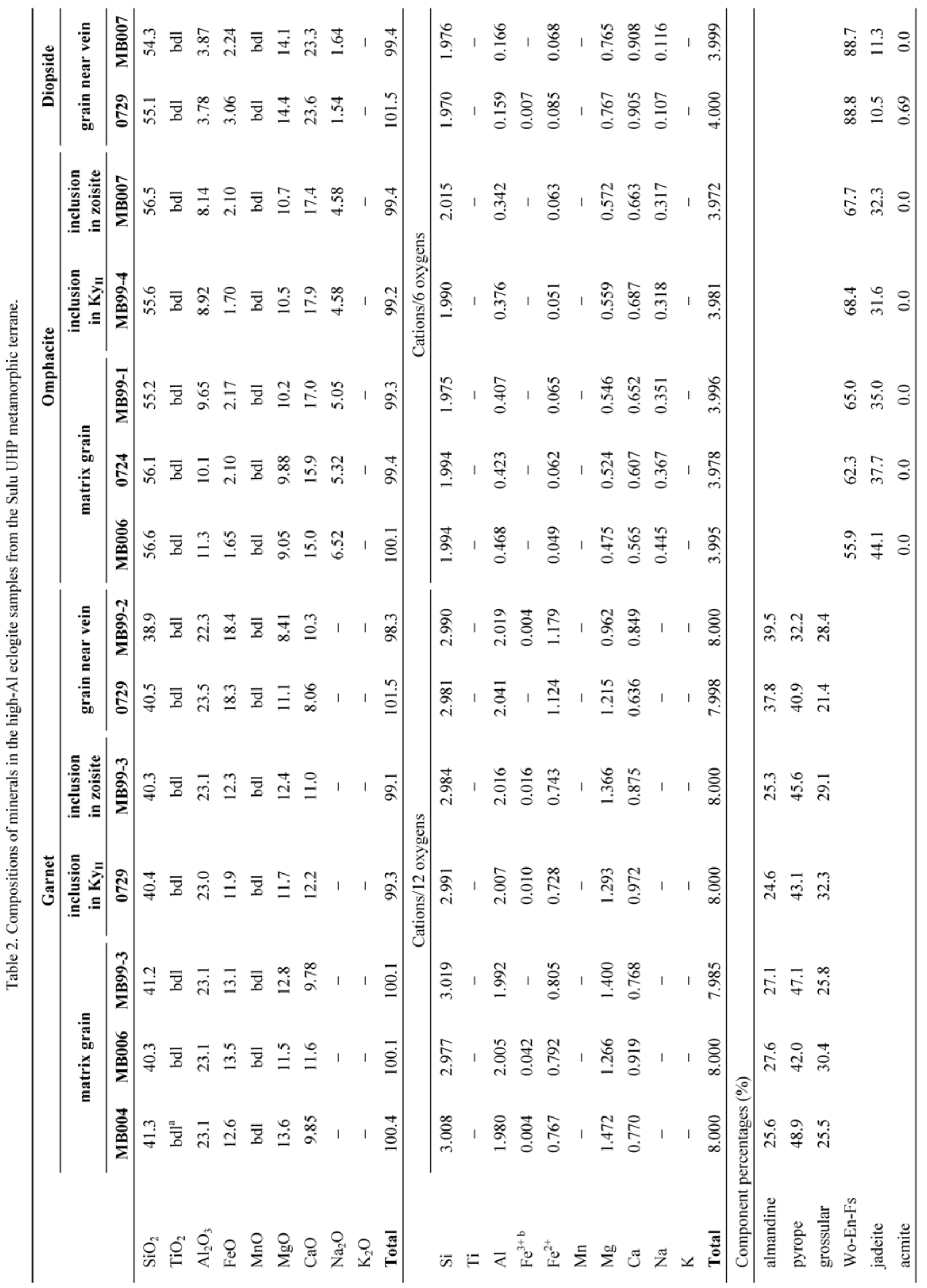




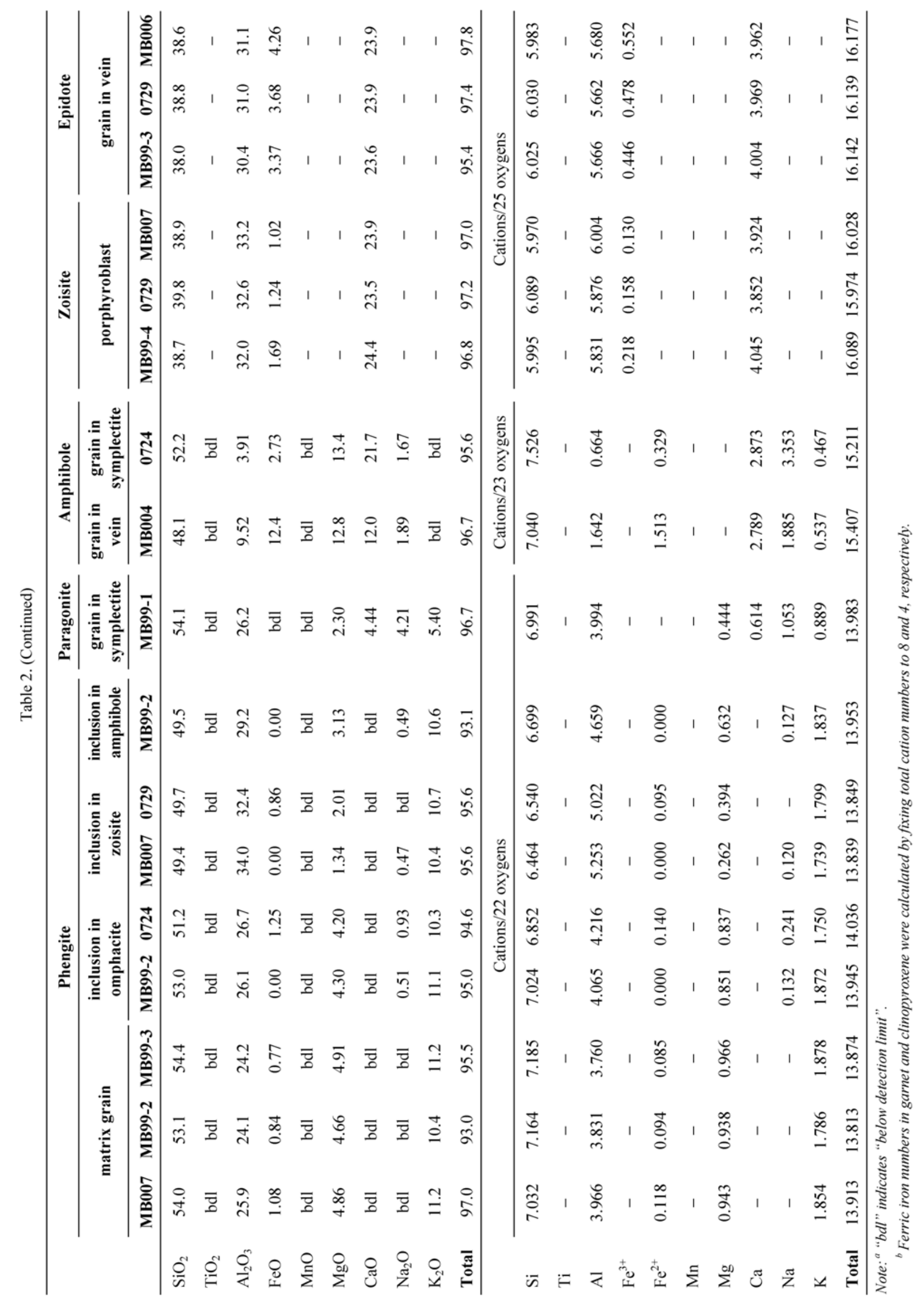


Sciences (IES), Academia Sinica, and with an energy dispersive spectrometer (EDS; Hitachi S-3000N) at the National Sun Yat-Sen University. The analytical conditions and data reduction are described in Liu et al. (2007).

Abundances of major oxides and trace elements were determined using a X-ray fluorescence (XRF) spectrometer at the University of Massachusetts and an inductively coupled plasma mass spectrometer (ICP-MS; Agilent 7500ce) at the Department of Earth Sciences, National Cheng-Kung University (NCKU) following the procedures of Liu et al. (2007). The accuracies and precisions were $<1 \%$ for XRF and $\sim 5 \%$ for ICP-MS analyses (Liu et al. 2007; Table 3). Low values for $\mathrm{Nb}, \mathrm{Ta}, \mathrm{Zr}, \mathrm{Hf}$, and La were confirmed by the standard addition method. The ICP-MS and XRF data for $\mathrm{Ti}, \mathrm{Sr}, \mathrm{Zr}, \mathrm{Y}, \mathrm{Cr}, \mathrm{Ni}$, and $\mathrm{Ba}$ generally agree with in $10 \%$ (Table 3). The relatively large differences of up to $70 \%$ for $\mathrm{Nb}$ and $\mathrm{Zr}$ reflect large uncertainty of XRF analysis for $\mathrm{Nb}<$ $1 \mathrm{ppm}$ and $\mathrm{Zr}<10 \mathrm{ppm}$. These differences do not affect data interpretation but confirm the low concentrations of these elements. The ICP-MS and XRF Ti data differ within $10 \%$, except for two samples with ICP values higher by $20-30 \%$, confirming complete dissolution of Fe-Ti oxides in the solutions for ICP-MS analysis.

$\mathrm{Sr}$ and $\mathrm{Nd}$ isotope ratios were measured by Thermal Ionization Mass Spectrometer (TIMS; Finnigan MAT262 and TRITON TI) at NCKU (Liu et al. 2007). The total procedural blanks were $<200 \mathrm{pg}$ for both $\mathrm{Sr}$ and $\mathrm{Nd}$. The ${ }^{87} \mathrm{Sr} /{ }^{86} \mathrm{Sr}$ ratios of NBS987 and BCR-2 measured from MAT262 were $0.710251 \pm 18(\mathrm{n}=5)$ and $0.705014 \pm 15(\mathrm{n}=4)$, respectively. The ${ }^{143} \mathrm{Nd} /{ }^{144} \mathrm{Nd}$ ratios from MAT262 were $0.512616 \pm 7(\mathrm{n}=4)$ for BCR-2. Measured on Triton, mean ${ }^{143} \mathrm{Nd} /{ }^{144} \mathrm{Nd}$ ratios were $0.511837 \pm 4(\mathrm{n}=3)$, and 0.512623 $\pm 5(\mathrm{n}=3)$ for La Jolla and BCR-2, respectively.

\section{RESULTS}

\subsection{Mineral Compositions, Equilibrium P-T, and Zoisite Formation Reaction}

In general, garnet, omphacite, and phengite are compositionally homogeneous. The constituent components of these phases (e.g., pyrope, as "Pyp", of garnet) vary within 7

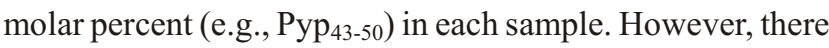
are larger variations among samples. As a whole, the composition of garnet varies in the range of $\mathrm{Alm}_{23-38} \mathrm{Pyp}_{35-50}$ $\mathrm{Grs}_{25-36} \mathrm{Sps}_{0-1.1}$, except for higher $\mathrm{Fe} / \mathrm{Mg}$ ratios $\left(\mathrm{Alm}_{33-47}\right.$ $\mathrm{Pyp}_{28-46}$ ) near fractures and retrograde veins (Table 2). Garnet inclusions in $\mathrm{Ky}_{\mathrm{II}}$ and zoisite are characterized by slightly lower pyrope proportions of $<45 \%$ (Table 2 ). Omphacite grains contain $24-48 \mathrm{~mol} \%$ jadeite and $<6.5 \mathrm{~mol} \%$ acmite with low jadeite proportions of $<42 \%$ for inclusions in $\mathrm{Ky}_{\text {II }}$ and zoisite (Table 2). Phengite grains and inclusions in garnet and omphacite have higher Si contents than inclusions in zoisite and amphibole (Table 2). It has been proposed that $\mathrm{Si}$ content in phengite increases with increasing pressure (Carswell and Harley 1990; Ravna and Terry 2004). The Ps value $\left[\mathrm{Fe}^{3+} /\left(\mathrm{Fe}^{3+}+\mathrm{Al}\right) \times 100\right]$ of zoisite porphyroblasts varies between 2 and 5 (Table 2), lower than that of epidote ( $\mathrm{Ps}=7-16)$ in the retrograde veins. Amphibole grains in symplectites have lower $\mathrm{Al}_{2} \mathrm{O}_{3}$ and higher $\mathrm{CaO}$ than those in the veins (Table 2). Diopside (4 - $14 \mathrm{~mol} \%$ jadeite; Table 2) is associated with amphibole and plagioclase. Some small rutile inclusions contain $\sim 0.5 \% \mathrm{CaO}$, implying a distinct origin from larger interstitial rutile.

Calculated from the garnet-clinopyroxene-phengite barometry (Ravna and Terry 2004) and garnet-clinopyroxene thermometery (Ravna 2000), garnet, omphacite and phengite were equilibrated at $36.1-39.2 \mathrm{~kb}$ and $760-835^{\circ} \mathrm{C}$ (Table 4 and Fig. 3), within the peak metamorphic P-T for most Sulu eclogites $\left(28-44 \mathrm{~kb}\right.$ and $680-890^{\circ} \mathrm{C}$; Zhang et al. 1995, 2006; Fig. 3). Zoisite porphyroblasts enclose garnet, omphacite, and kyanite grains, implying crystallization with expense of the enclosed phases. This inference is supported by the reaction of

7 grossular +3 hendenburgite +12 kyanite $+6 \mathrm{H}_{2} \mathrm{O} \rightarrow$ almandine +12 zoisite

which is derived from a thermodynamically based software, THERMOCALC 3.21, using mineral compositions as input parameters (Holland and Powell 1998). THERMOCALC 3.21 also calculates that the zoisite formation reaction occurred along trajectories of decreasing pressure and increasing temperature, intercepting the P-T paths of the Sulu eclogites at $\sim 17 \mathrm{kbar}$ and $\sim 750^{\circ} \mathrm{C}$ (Fig. 3). This inferred P-T for zoisite formation is comparable to that for the crystallization of hydrous porphyroblasts in other Sulu eclogites during stage III retrogression (Fig. 3; Zhang et al. 1995). Evidently, the high-Al eclogite samples and most Sulu eclogites underwent a common metamorphic P-T path.

\subsection{Bulk Compositions}

The eclogites samples have high $\mathrm{Al}_{2} \mathrm{O}_{3}$ contents of $18.4-29.2 \%$ with other major oxide contents in the ranges of basalts and gabbros (Table 3). Abundance of $\mathrm{TiO}_{2}$, a relatively immobile element, is lower than that of most basalts $(>0.7 \%)$, implying derivation from gabbroic cumulate protoliths. However, the inverse $\mathrm{SiO}_{2}-\mathrm{Al}_{2} \mathrm{O}_{3}$ and $\mathrm{Al}_{2} \mathrm{O}_{3}-\mathrm{CaO}$ correlations are inconsistent with magmatic cumulates (Fig. 4).

The samples show prominent REE-HFSE fractionations (Fig. 5a). Four samples, MB004, MB006, MB99-2, and 0724, are characterized by HFSE enrichments relative to REE with similar compatibility (Fig. 5a). These four samples are referred to as group I. The group I samples are also characterized by LREE depletions, slight Eu enrichment, and $<30 \%$ variations in HREE abundances (Fig. 5b). Referred to as group II, other five samples have subchondritic $\mathrm{Nb} / \mathrm{La}$ ratios 
Table 3. Major (in wt\%) and trace element (in ppm) abundances for the high-Al eclogite samples.

\begin{tabular}{|c|c|c|c|c|c|c|c|c|c|c|c|}
\hline & \multicolumn{4}{|c|}{ group I eclogite samples } & \multicolumn{5}{|c|}{ group II eclogite samples } & \multirow{2}{*}{$\begin{array}{c}\text { standard } \\
\text { measurements }\end{array}$} & \multirow{2}{*}{$\begin{array}{c}\text { reference } \\
\text { values }^{\text {b }}\end{array}$} \\
\hline & MB004 & MB006 & MB99-2 & 0724 & 0729 & MB007 & MB99-1 & MB99-3 & MB99-4 & & \\
\hline $\mathrm{SiO}_{2}$ & 45.0 & 49.5 & 41.9 & 45.9 & 41.5 & 43.9 & 43.9 & 42.1 & 44.4 & & \\
\hline $\mathrm{TiO}_{2}$ & 0.61 & 0.66 & 0.45 & 0.53 & 0.21 & 0.23 & 0.31 & 0.23 & 0.48 & & \\
\hline $\mathrm{Al}_{2} \mathrm{O}_{3}$ & 21.7 & 18.4 & 28.6 & 22.4 & 29.2 & 25.2 & 25.8 & 26.8 & 25.1 & & \\
\hline $\mathrm{FeO}_{\text {tot }}$ & 7.86 & 4.82 & 7.29 & 6.27 & 7.95 & 7.45 & 6.91 & 8.46 & 7.00 & & \\
\hline $\mathrm{MnO}$ & 0.13 & 0.08 & 0.12 & 0.10 & 0.14 & 0.13 & 0.12 & 0.13 & 0.11 & & \\
\hline $\mathrm{MgO}$ & 11.3 & 10.0 & 9.16 & 10.1 & 9.30 & 9.10 & 9.43 & 10.3 & 8.59 & & \\
\hline $\mathrm{CaO}$ & 11.6 & 13.0 & 10.4 & 12.0 & 10.3 & 12.0 & 11.4 & 10.7 & 12.6 & & \\
\hline $\mathrm{Na}_{2} \mathrm{O}$ & 1.90 & 3.66 & 1.61 & 2.61 & 1.22 & 1.53 & 2.17 & 1.13 & 1.57 & & \\
\hline $\mathrm{K}_{2} \mathrm{O}$ & 0.03 & 0.09 & 0.05 & 0.06 & 0.08 & 0.17 & 0.07 & 0.33 & 0.30 & & \\
\hline $\mathrm{P}_{2} \mathrm{O}_{5}$ & 0.02 & 0.01 & 0.01 & 0.01 & 0.01 & 0.02 & 0.01 & 0.01 & 0.01 & & \\
\hline Total $^{\mathrm{c}}$ & 100.2 & 100.3 & 99.7 & 100.1 & 99.8 & 99.8 & 100.1 & 100.3 & 100.2 & & \\
\hline LOI & 0.73 & 0.93 & 0.55 & 0.52 & 0.46 & 1.11 & 0.54 & 0.82 & 0.85 & & \\
\hline $\mathrm{Sc}$ & 30.8 & 33.6 & 32.0 & 40.0 & 31.0 & 24.8 & 40.8 & 9.2 & 13.5 & $42.8 \pm 1.0$ & 44.0 \\
\hline $\mathrm{Cr}$ & $361(388)^{d}$ & $842(950)$ & 309 & 576 & $224(231)$ & $62(82.0)$ & $656(675)$ & 24 & $525(581)$ & $380 \pm 6(297)$ & $382(280)$ \\
\hline $\mathrm{Ni}$ & $265(280)$ & $285(311)$ & 183 & 246 & $122(118)$ & $152(140)$ & 195(195) & 181 & $138(142)$ & $165 \pm 2(113)$ & $166(119)$ \\
\hline $\mathrm{Rb}$ & 1.12 & 2.67 & 2.49 & 2.25 & 2.54 & 6.34 & 2.77 & 10.9 & 9.28 & $0.244 \pm 0.019$ & 0.24 \\
\hline $\mathrm{Ba}$ & $24.9(36)$ & $53.3(59)$ & 73.5 & 44.4 & $40.8(47)$ & $41.6(47)$ & $23.7(31)$ & 45.7 & $48.3(54)$ & $6.27 \pm 0.20(134)$ & $6.40(130)$ \\
\hline $\mathrm{Sr}$ & $44.2(42)$ & $55.1(54)$ & 30.1 & 49.1 & $107(95)$ & $492(441)$ & $140(135)$ & 138 & $496(504)$ & $112 \pm 3(385)$ & $110(389)$ \\
\hline $\mathrm{Y}$ & $3.14(3.3)$ & $2.42(2.7)$ & 3.62 & 3.31 & $3.68(3.7)$ & $3.05(2.9)$ & $5.93(5.6)$ & 1.95 & $3.22(3.3)$ & $16.5 \pm 0.2(25.4)$ & $16.5(26)$ \\
\hline $\mathrm{Nb}$ & $0.55(0.9)$ & $0.48(0.9)$ & 0.27 & 0.35 & $0.14(0.4)$ & $0.08(0.3)$ & $1.43(1.6)$ & 0.11 & $0.47(0.6)$ & $0.553 \pm 0.014(18.5)$ & $0.55(18)$ \\
\hline $\mathrm{Ta}$ & 0.02 & 0.02 & 0.02 & 0.01 & 0.01 & 0.01 & 0.03 & 0.01 & 0.02 & $0.030 \pm 0.001$ & $0.041^{\mathrm{e}}$ \\
\hline $\mathrm{Ti}$ & $\begin{array}{c}3697 \\
(3628)\end{array}$ & $\begin{array}{c}3945 \\
(3977)\end{array}$ & $\begin{array}{c}3525 \\
(2719)\end{array}$ & $\begin{array}{c}3528 \\
(3199)\end{array}$ & $\begin{array}{c}1539 \\
(1270)\end{array}$ & $\begin{array}{c}1516 \\
(1390)\end{array}$ & $\begin{array}{c}1986 \\
(1872)\end{array}$ & $\begin{array}{c}1419 \\
(1392)\end{array}$ & $\begin{array}{c}2758 \\
(2899)\end{array}$ & $\begin{array}{c}5609 \pm 107 \\
(16663)\end{array}$ & $\begin{array}{c}5755 \\
(16364)\end{array}$ \\
\hline $\mathrm{Zr}$ & $7.98(10)$ & $7.44(10)$ & 4.73 & 7.92 & $3.29(4)$ & $2.71(6)$ & $3.81(5)$ & 4.35 & $3.27(7)$ & $15.0 \pm 0.3(178)$ & $14.5(172)$ \\
\hline Hf & 0.231 & 0.239 & 0.136 & 0.250 & 0.096 & 0.080 & 0.122 & 0.117 & 0.100 & $0.523 \pm 0.003$ & 0.56 \\
\hline $\mathrm{La}$ & 0.134 & 0.101 & 0.073 & 0.054 & 0.484 & 2.61 & 3.06 & 0.950 & 5.71 & $0.583 \pm 0.007$ & 0.58 \\
\hline $\mathrm{Ce}$ & 0.443 & 0.179 & 0.117 & 0.097 & 0.901 & 4.77 & 6.15 & 1.60 & 10.6 & $1.857 \pm 0.022$ & 1.85 \\
\hline $\operatorname{Pr}$ & 0.039 & 0.030 & 0.019 & 0.014 & 0.109 & 0.624 & 0.765 & 0.201 & 1.31 & $0.370 \pm 0.007$ & 0.37 \\
\hline $\mathrm{Nd}$ & 0.215 & 0.214 & 0.146 & 0.136 & 0.501 & 2.68 & 2.97 & 0.863 & 5.13 & $2.346 \pm 0.037$ & 2.35 \\
\hline $\mathrm{Sm}$ & 0.125 & 0.090 & 0.103 & 0.081 & 0.152 & 0.645 & 0.669 & 0.199 & 1.08 & $1.085 \pm 0.023$ & 1.10 \\
\hline Eu & 0.117 & 0.075 & 0.123 & 0.086 & 0.129 & 0.389 & 0.230 & 0.177 & 0.517 & $0.503 \pm 0.003$ & 0.52 \\
\hline Gd & 0.327 & 0.202 & 0.345 & 0.271 & 0.350 & 0.615 & 0.769 & 0.240 & 0.896 & $1.845 \pm 0.033$ & 1.97 \\
\hline $\mathrm{Tb}$ & 0.065 & 0.040 & 0.078 & 0.061 & 0.077 & 0.089 & 0.150 & 0.036 & 0.124 & $0.389 \pm 0.006$ & 0.38 \\
\hline Dy & 0.466 & 0.329 & 0.549 & 0.484 & 0.559 & 0.491 & 0.904 & 0.274 & 0.582 & $2.432 \pm 0.016$ & 2.50 \\
\hline Ho & 0.104 & 0.071 & 0.115 & 0.107 & 0.116 & 0.094 & 0.185 & 0.052 & 0.096 & $0.569 \pm 0.007$ & 0.57 \\
\hline Er & 0.342 & 0.237 & 0.352 & 0.325 & 0.342 & 0.284 & 0.534 & 0.192 & 0.281 & $1.701 \pm 0.013$ & 1.70 \\
\hline $\operatorname{Tm}$ & 0.052 & 0.035 & 0.049 & 0.047 & 0.047 & 0.039 & 0.076 & 0.028 & 0.038 & $0.267 \pm 0.001$ & 0.27 \\
\hline $\mathrm{Yb}$ & 0.325 & 0.213 & 0.300 & 0.281 & 0.280 & 0.238 & 0.439 & 0.183 & 0.227 & $1.612 \pm 0.024$ & 1.60 \\
\hline $\mathrm{Lu}$ & 0.051 & 0.033 & 0.044 & 0.043 & 0.042 & 0.036 & 0.062 & 0.029 & 0.033 & $0.247 \pm 0.003$ & 0.25 \\
\hline Th & 0.022 & 0.018 & 0.026 & 0.017 & 0.112 & 0.578 & 0.689 & 0.171 & 0.961 & $0.032 \pm 0.001$ & 0.030 \\
\hline $\mathrm{U}$ & 0.015 & 0.013 & 0.012 & 0.013 & 0.022 & 0.133 & 0.098 & 0.087 & 0.217 & $0.009 \pm 0.0003$ & 0.010 \\
\hline
\end{tabular}

Note: ${ }^{a}$ Averages and standard deviations (2 $\left.\sigma\right)$ from four ICP analyses on standard BIR-1, except for the values in parentheses, which are results from $X R F$ analysis on standard BHVO-2.

${ }^{b}$ Reference values for BIR-1 are from Eggins et al. (1997), except for the Tm value from Gladney and Roelandts (1988). In parentheses are reference values for BHVO-2 (Wilson 1997).

c "Dry" total measured from glassy disc made from $950^{\circ} \mathrm{C}$-heated sample powder.

${ }^{d} X R F$ data are reported in parentheses.

${ }^{e}$ Eggins et al. (1997) preferred a reference value of 0.060 for Ta; however, their measured value was 0.041 . 
Table 4. Mineral compositions for the high-Al eclogite samples and associated equilibrium pressure and temperature.

\begin{tabular}{|c|c|c|c|c|c|c|c|c|c|c|c|c|c|c|c|}
\hline & \multicolumn{3}{|c|}{ MB006 } & \multicolumn{3}{|c|}{ MB006 } & \multicolumn{3}{|c|}{ MB007 } & \multicolumn{3}{|c|}{0729} & \multicolumn{3}{|c|}{0729} \\
\hline & Grt & Omp & Phen & Grt & Omp & Phen & Grt & Omp & Phen & Grt & Omp & Phen & Grt & Omp & Phen \\
\hline $\mathrm{SiO}_{2}$ & 40.9 & 57.2 & 53.3 & 41.0 & 56.8 & 54.5 & 41.5 & 56.3 & 52.9 & 41.1 & 57.0 & 53.5 & 41.2 & 57.7 & 51.2 \\
\hline $\mathrm{TiO}_{2}$ & 0.04 & 0.05 & 0.24 & 0.03 & 0.05 & 0.25 & 0.02 & 0.16 & 0.31 & 0.06 & 0.09 & 0.22 & 0.03 & 0.04 & 0.20 \\
\hline $\mathrm{Al}_{2} \mathrm{O}_{3}$ & 22.6 & 10.0 & 26.0 & 22.5 & 8.85 & 26.3 & 23.5 & 10.2 & 26.7 & 23.5 & 9.4 & 27.1 & 23.1 & 10.4 & 27.7 \\
\hline $\mathrm{Cr}_{2} \mathrm{O}_{3}$ & 0.14 & 0.10 & 0.16 & 0.05 & 0.05 & 0.07 & 0.08 & 0.11 & $\mathrm{bdl}^{1}$ & 0.01 & bdl & 0.02 & 0.01 & 0.01 & 0.05 \\
\hline $\mathrm{FeO}$ & 12.1 & 1.62 & 0.90 & 12.7 & 1.61 & 0.92 & 12.2 & 1.43 & 0.96 & 12.6 & 2.00 & 1.22 & 13.6 & 1.94 & 1.02 \\
\hline $\mathrm{MnO}$ & 0.20 & 0.01 & 0.03 & 0.19 & $\mathrm{bdl}^{\mathrm{a}}$ & 0.02 & 0.18 & bdl & 0.03 & 0.12 & bdl & bdl & 0.222 & bdl & bdl \\
\hline $\mathrm{MgO}$ & 12.6 & 11.1 & 4.96 & 11.9 & 11.8 & 4.90 & 12.1 & 10.3 & 4.28 & 11.8 & 11.2 & 4.89 & 11.3 & 10.58 & 4.70 \\
\hline $\mathrm{CaO}$ & 12.2 & 15.5 & 0.02 & 12.2 & 16.7 & bdl & 12.1 & 15.7 & bdl & 11.4 & 16.8 & 0.06 & 11.7 & 15.5 & 0.01 \\
\hline $\mathrm{Na}_{2} \mathrm{O}$ & - & 5.63 & 0.37 & - & 4.89 & 0.47 & - & 5.41 & 0.29 & - & 4.81 & 0.475 & - & 5.67 & 0.504 \\
\hline $\mathrm{K}_{2} \mathrm{O}$ & - & - & 10.6 & - & - & 10.2 & - & - & 10.3 & - & - & 10.2 & - & - & 10.2 \\
\hline Total & 100.7 & 101.3 & 96.6 & 100.5 & 100.7 & 97.6 & 101.7 & 99.7 & 95.7 & 100.5 & 101.3 & 97.7 & 101.2 & 101.8 & 95.6 \\
\hline $\mathrm{Si}$ & 2.979 & 1.992 & 6.962 & 3.002 & 1.994 & 7.012 & 2.999 & 1.991 & 6.952 & 3.002 & 1.990 & 6.890 & 3.008 & 1.998 & 6.744 \\
\hline $\mathrm{Ti}$ & 0.002 & 0.001 & 0.024 & 0.002 & 0.001 & 0.024 & 0.001 & 0.004 & 0.030 & 0.003 & 0.002 & 0.022 & 0.002 & 0.001 & 0.020 \\
\hline $\mathrm{Al}$ & 1.938 & 0.412 & 4.000 & 1.945 & 0.366 & 3.988 & 1.999 & 0.427 & 4.128 & 2.026 & 0.386 & 4.118 & 1.991 & 0.424 & 4.306 \\
\hline $\mathrm{Cr}$ & 0.008 & 0.002 & 0.016 & 0.003 & 0.001 & 0.008 & 0.005 & 0.003 & - & 0.001 & - & 0.002 & 0.001 & 0.000 & 0.006 \\
\hline $\mathrm{Fe}^{3+\mathrm{b}}$ & 0.091 & - & - & 0.044 & - & - & - & - & - & - & - & 0.046 & - & - & 0.078 \\
\hline $\mathrm{Fe}^{2+}$ & 0.648 & 0.047 & 0.098 & 0.732 & 0.047 & 0.098 & 0.737 & 0.042 & 0.106 & 0.771 & 0.058 & 0.086 & 0.829 & 0.056 & 0.034 \\
\hline Mn & 0.012 & 0.000 & 0.004 & 0.012 & - & 0.002 & 0.011 & - & 0.004 & 0.007 & - & - & 0.014 & - & - \\
\hline $\mathrm{Mg}$ & 1.370 & 0.577 & 0.966 & 1.299 & 0.617 & 0.940 & 1.307 & 0.544 & 0.838 & 1.281 & 0.585 & 0.938 & 1.233 & 0.546 & 0.924 \\
\hline $\mathrm{Ca}$ & 0.952 & 0.578 & 0.002 & 0.962 & 0.628 & - & 0.940 & 0.594 & - & 0.892 & 0.629 & 0.008 & 0.918 & 0.573 & 0.002 \\
\hline $\mathrm{Na}$ & - & 0.380 & 0.094 & - & 0.333 & 0.118 & - & 0.371 & 0.074 & - & 0.326 & 0.120 & - & 0.381 & 0.128 \\
\hline $\mathrm{K}$ & - & - & 1.772 & - & - & 1.672 & - & - & 1.720 & - & - & 1.680 & - & - & 1.726 \\
\hline Total & 8.000 & 3.990 & 13.938 & 8.000 & 3.988 & 13.860 & 7.998 & 3.976 & 13.850 & 7.982 & 3.977 & 13.906 & 7.994 & 3.980 & 13.968 \\
\hline $\begin{array}{l}\mathrm{P} 1^{\mathrm{c}} \\
(\mathrm{kb})\end{array}$ & \multicolumn{3}{|c|}{$31.7(4.56)^{c}$} & \multicolumn{3}{|c|}{$29.5(4.56)$} & \multicolumn{3}{|c|}{$32.2(3.57)$} & \multicolumn{3}{|c|}{$28.2(2.95)$} & \multicolumn{3}{|c|}{$27.3(2.35)$} \\
\hline $\begin{array}{l}\mathrm{P} 2^{\mathrm{d}} \\
(\mathrm{kb})\end{array}$ & \multicolumn{3}{|c|}{$39.2[1]^{\mathrm{e}}$} & \multicolumn{3}{|c|}{$37.3[2]$} & \multicolumn{3}{|c|}{$36.4[3]$} & \multicolumn{3}{|c|}{$37.6[4]$} & \multicolumn{3}{|c|}{$36.1[5]$} \\
\hline $\begin{array}{l}\mathrm{T} 2^{\mathrm{d}} \\
\left({ }^{\circ} \mathrm{C}\right)\end{array}$ & \multicolumn{3}{|c|}{835 [6] } & \multicolumn{3}{|c|}{770 [7] } & \multicolumn{3}{|c|}{$760[8]$} & \multicolumn{3}{|c|}{825 [9] } & \multicolumn{3}{|c|}{$800[10]$} \\
\hline
\end{tabular}

Note: " "bdl" indicates "below detection limit".

${ }^{b}$ Ferric iron numbers for garnet and omphacite were calculated as in Table 2. Those for phengite were calculated by fixing the sum of tetrahedral and octahedral cation numbers to 12.1 .

${ }^{c} \mathrm{Pl}$ is average pressure at constant temperature of $750^{\circ} \mathrm{C}$, calculated by THERMOCALC 3.21 (Holland and Powell 1998 ) with error indicated in parentheses.

${ }^{d}$ P2 and T2 were constrained from the garnet-clinopyroxene-phengite barometry (Ravna and Terry 2004) and the garnet-clinopyroxene thermometery (Ravna 2000).

${ }^{e}$ The numbers in brackets denote the lines labeled with correspondent numbers in Fig. 3. These lines were calculated from the reaction equilibria of diopside + muscovite $=$ grossular + pyrope + celadonite $[1-5]$ and Fe-Mg exchange $K_{D}$ for the garnet-clinopyroxene thermometer $[6-10]$ using relevant mineral compositions. As an example, the interception of line 1 and 6 in Fig. 3 determines the P2 and T2 of sample MB006. 
without Ti anomaly (Fig. 5a). Their HREE contents mostly vary within a factor of 2 (Table 3 ) and $\mathrm{La} / \mathrm{Yb}$ ratio ranges from near chondritic to superchondritic values (Fig. 5b). The group II samples have higher Th and U contents than the group I samples (Fig. 5a).

\section{3 $\mathrm{Sr}$ and $\mathrm{Nd}$ Isotopes}

${ }^{87} \mathrm{Sr} /{ }^{86} \mathrm{Sr}$ and ${ }^{143} \mathrm{Nd} /{ }^{144} \mathrm{Nd}$ ratios range from 0.70469 to 0.70567 and 0.51229 to 0.51279 , respectively (Table 5). After corrected to the time of metamorphism, $220 \mathrm{Ma}$ (e.g., Li et al. 1993, 2000; Ames et al. 1996), all the samples have similar metamorphic initial ${ }^{87} \mathrm{Sr} /{ }^{86} \mathrm{Sr}$ and ${ }^{143} \mathrm{Nd} /{ }^{144} \mathrm{Nd}$ ratios (Fig. 6). On the $\varepsilon_{\mathrm{Nd}}(220 \mathrm{Ma})$ versus $\left({ }^{87} \mathrm{Sr} /{ }^{86} \mathrm{Sr}\right)_{220 \mathrm{Ma}}$ plot, the samples fall on the mantle array within the field for the Sulu high-Fe-Ti eclogites (Fig. 6), whose protoliths were inferred to be layered intrusions formed in continental or arc settings (Liu et al. 2007).

\section{DISCUSSION}

The samples of this study differ from most Sulu eclogites for strong HFSE-REE fractionations, high $\mathrm{Al}_{2} \mathrm{O}_{3}$ of $18.4-29.2 \%$ accompanied by high $\mathrm{MgO}$ of $8.59-11.3 \%$, and the coexistence of $\mathrm{Ky}_{\mathrm{I}}$ and $\mathrm{Ky}_{\mathrm{II}}$. The causes of these features are addressed to better understand chemical evolution for subduction and exhumation of continental crust.

\subsection{Mechanisms and Timing for Kyanite and Zoisite Formation}

The coexistence of granular and irregular-shaped kyan-

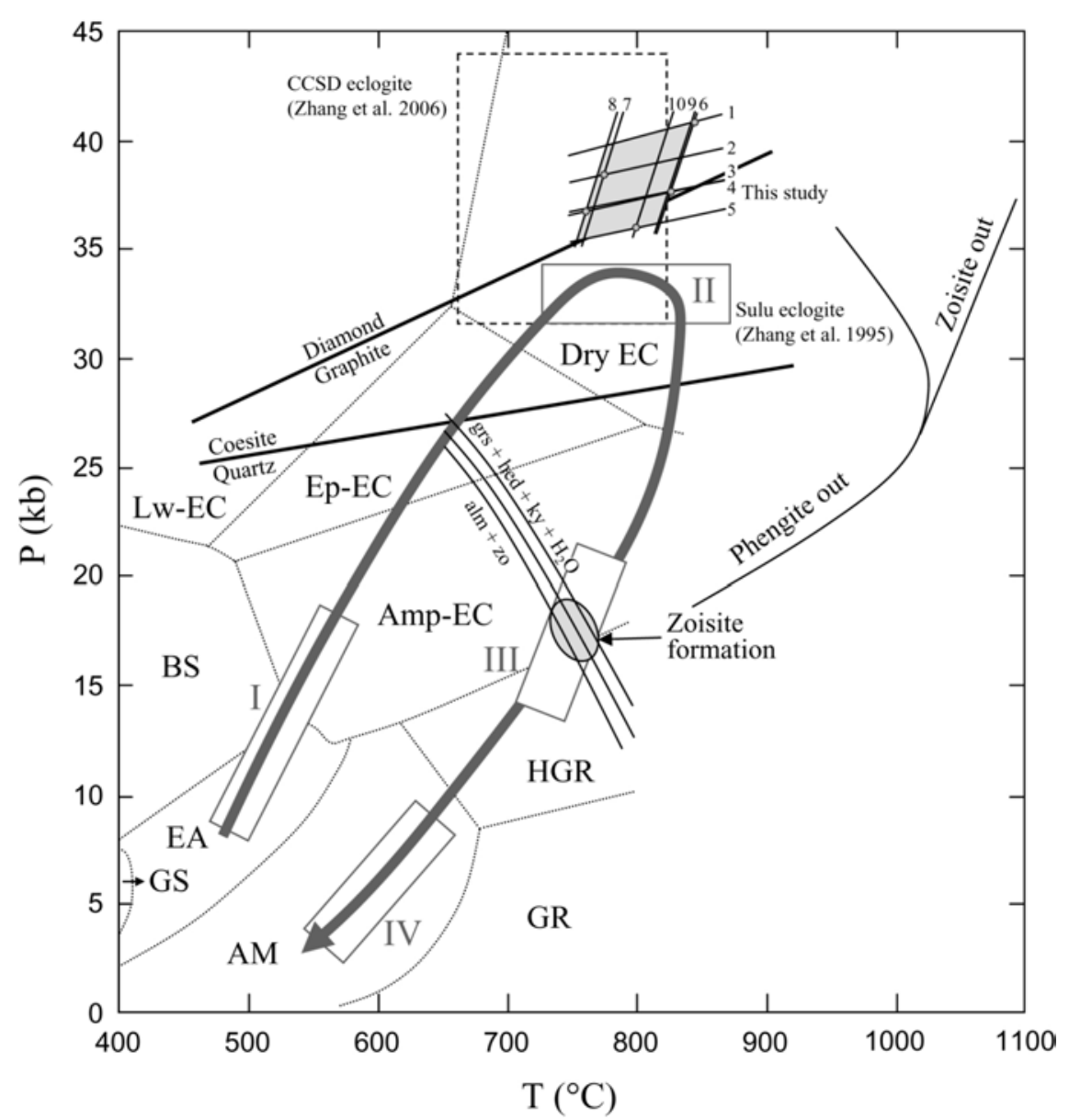

Fig. 3. Comparing the peak metamorphic P-T conditions for the studied samples (grey area) and CCSD kyanite- and phengite-eclogites (dashed rectangular; Zhang et al. 2006) to the P-T path of Zhang et al. (1995) for Sulu eclogites. The peak metamorphic pressure (lines 1 to 5) was calculated from reaction of diopside + muscovite $=$ grossular + pyrope + celadonite $($ Ravna and Terry 2004) and peak temperature (lines 6 - 10) was calculated from garnet/omphacite Fe-Mg exchange reaction (Ravna 2000). Four metamorphic stages labeled I - IV were proposed for the Sulu eclogites (Zhang et al. 1995). Calculated from "THERMOCALC 3.21" using mineral compositions from three different samples, the P-T trajectories for zoisite formation encounter the P-T conditions for stage III, at which hydrous porphyroblasts crystallized. Also shown is the distribution of metamorphic facies (Dry EC: dry eclogite facies; Lw-EC: lowsonite-eclogite facies; Ep-EC: epidote-eclogite facies; Amp-EC: amphibole-eclogite facies; BS: blueschist facies; HGR: kyanite-bearing granulite facies; GS: greenschist facies; EA: epidote-amphibolite facies; AM: amphibolite facies; GR: granulite facies). 
ite $\left(\mathrm{Ky}_{\mathrm{I}}\right.$ and $\mathrm{Ky}_{\mathrm{II}}$, respectively; Figs. $\left.2 \mathrm{~b}-\mathrm{d}\right)$ has been reported for other Sulu eclogites (Zhang et al. 1995). However, its formation mechanism has not yet been addressed. Kyanite eclogites are mostly metamorphosed from high-Al mafic rocks (e.g., Becker et al. 1999; John and Schenk 2003). As products from surface alteration, mixtures of mafic igneous rocks and clays have also been proposed as alternative protoliths (Enami and Nagasaki 1999). Low MgO contents and high ${ }^{87} \mathrm{Sr} /{ }^{86} \mathrm{Sr}$ ratios off the mantle array in the ${ }^{87} \mathrm{Sr} /{ }^{86} \mathrm{Sr}-{ }^{143} \mathrm{Nd} /{ }^{144} \mathrm{Nd}$ space are the characteristics of such mixtures (e.g., Innocent et al. 1997; Ma et al. 2007) but not observed in the studied samples. At metamorphic P-T conditions, plagioclase in mafic rocks decomposes to form kyanite and other minerals with or without the presence of water (Wayte et al. 1989). The reactions are:
3 anorthite $\rightarrow 1$ grossular +2 kyanite +1 quartz

and

4 anorthite +1 water $\rightarrow 2$ zoisite +1 kyanite +1 quartz

Exemplified by the Zambian eclogites, reaction (2) resulted in garnet laths intergrown with kyanite, quartz, and omphacite grains $(<50 \mu \mathrm{m})$, replacing former plagioclase (Fig. 5 of John and Schenk 2003). As our $\mathrm{Ky}_{\mathrm{I}}$, matrix kyanite grains $(\sim 250 \mu \mathrm{m})$ in some Austroalpine eclogites are texturally in equilibrium with garnet and omphacite without plagioclase relicts. They were also considered as products from prograde plagioclase breakdown (Sassi et al. 2004). Similar petrographic texture could develop from

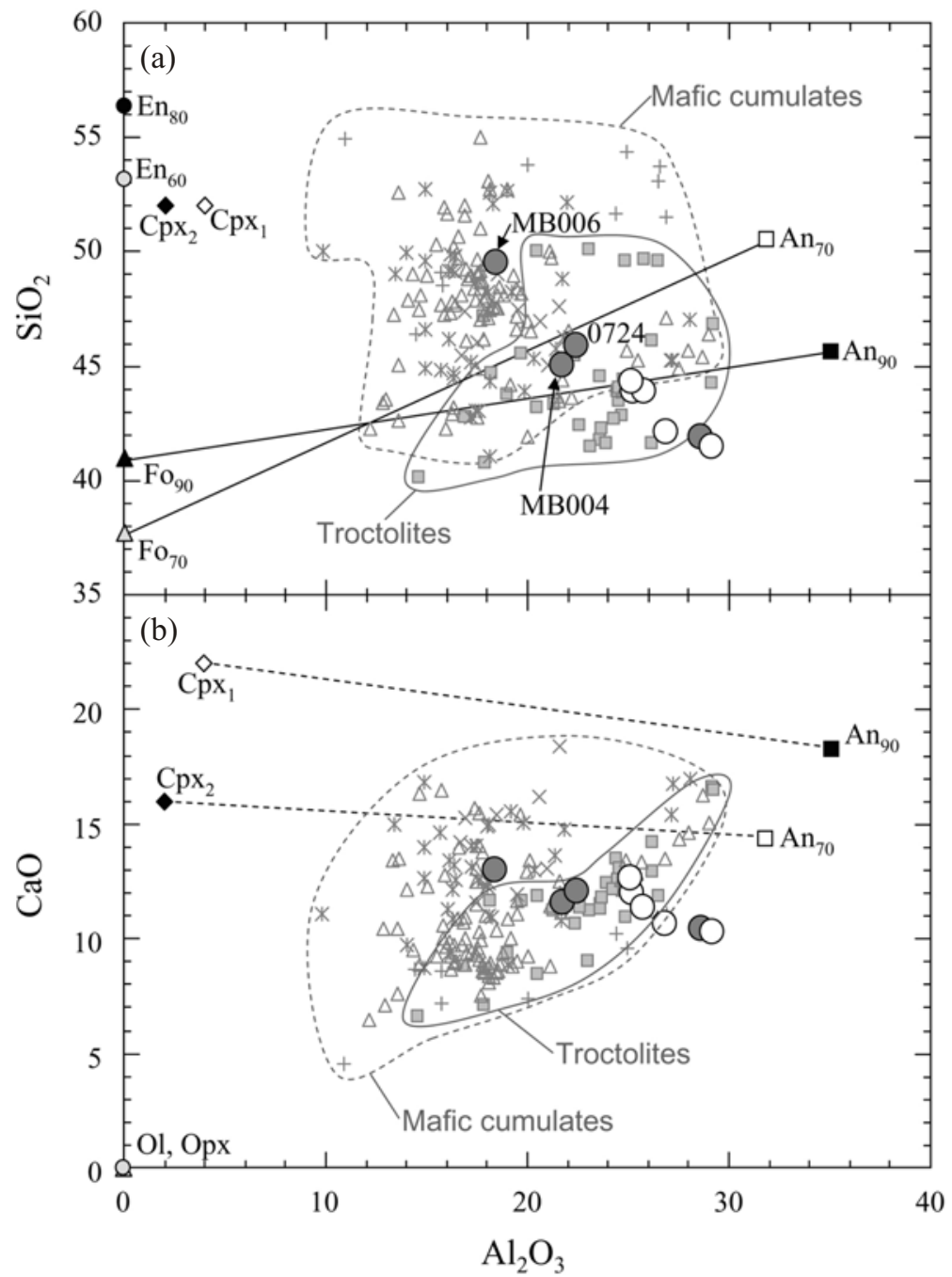

$\bigcirc$ group I eclogite samples
$\bigcirc$ group II eclogite samples
$\square$ Troctolites
$*$ Gabbronorites
$\times$ Olivine gabbros
+ Norites
$\triangle$ High-Al gabbros

Fig. 4. Abundance of $\mathrm{Al}_{2} \mathrm{O}_{3}$ versus (a) $\mathrm{SiO}_{2}$ and (b) $\mathrm{CaO}$ contents comparing the samples to mafic cumulates (troctolites: Benoit et al. 1996; Turner 1996; Mark1 2001; Lissenberg et al. 2005; gabbronorites: Greene et al. 2006; olivine gabbros: Benoit et al. 1996; Turner 1996; norites: Turner 1996; Markl 2001; Maji and Sarkar 2004; high-Al gabbros: Mitchell et al. 1995). The samples form inverse correlation trends extending to higher $\mathrm{Al}_{2} \mathrm{O}_{3}$ but lower $\mathrm{SiO}_{2}$ and $\mathrm{CaO}$ contents than that of the cumulates. The compositions of cumulate minerals are also shown. See the footnote of Table 6 for the compositions of $\mathrm{Cpx}_{1}$ and $\mathrm{Cpx}_{2}$ (Greene et al. 2006). 
metamorphic breakdown of lawsonite (e.g., Li et al. 2004), which is an index mineral for subduction of cold oceanic slab (Clarke et al. 2006). However, the absence of lawsonite, hot subduction (Zhang et al. 1995; Fig. 3), and the continental affinity for the samples are inconsistent with lawsonite precursor. Therefore, we propose that most $\mathrm{Ky}_{\mathrm{I}}$ grains in the samples were formed from plagioclase breakdown.

$\mathrm{Ky}_{\text {II }}$ grains show textures distinct from the apparent garnet-omphacite- $\mathrm{Ky}_{\mathrm{I}}$ equilibration. They occur as networks mostly on garnet matrix (Fig. 2c) and as porphyroblasts containing anhedral garnet and subordinate amounts of omphacite inclusions (Fig. 2d). These textures can be explained by $\mathrm{Ky}_{\mathrm{II}}$ crystallization with the expense of garnet. Highpressure fluids released from metamorphism (e.g., Zheng et al. 2003; Li et al. 2004; Sheng et al. 2007) could play a role for garnet consumption and kyanite precipitation. Based on a theoretical analysis, Manning (2004) concluded that the dominant solutes in deep fluids are $\mathrm{Si}, \mathrm{Na}, \mathrm{Ca}$, and $\mathrm{Al}$. In
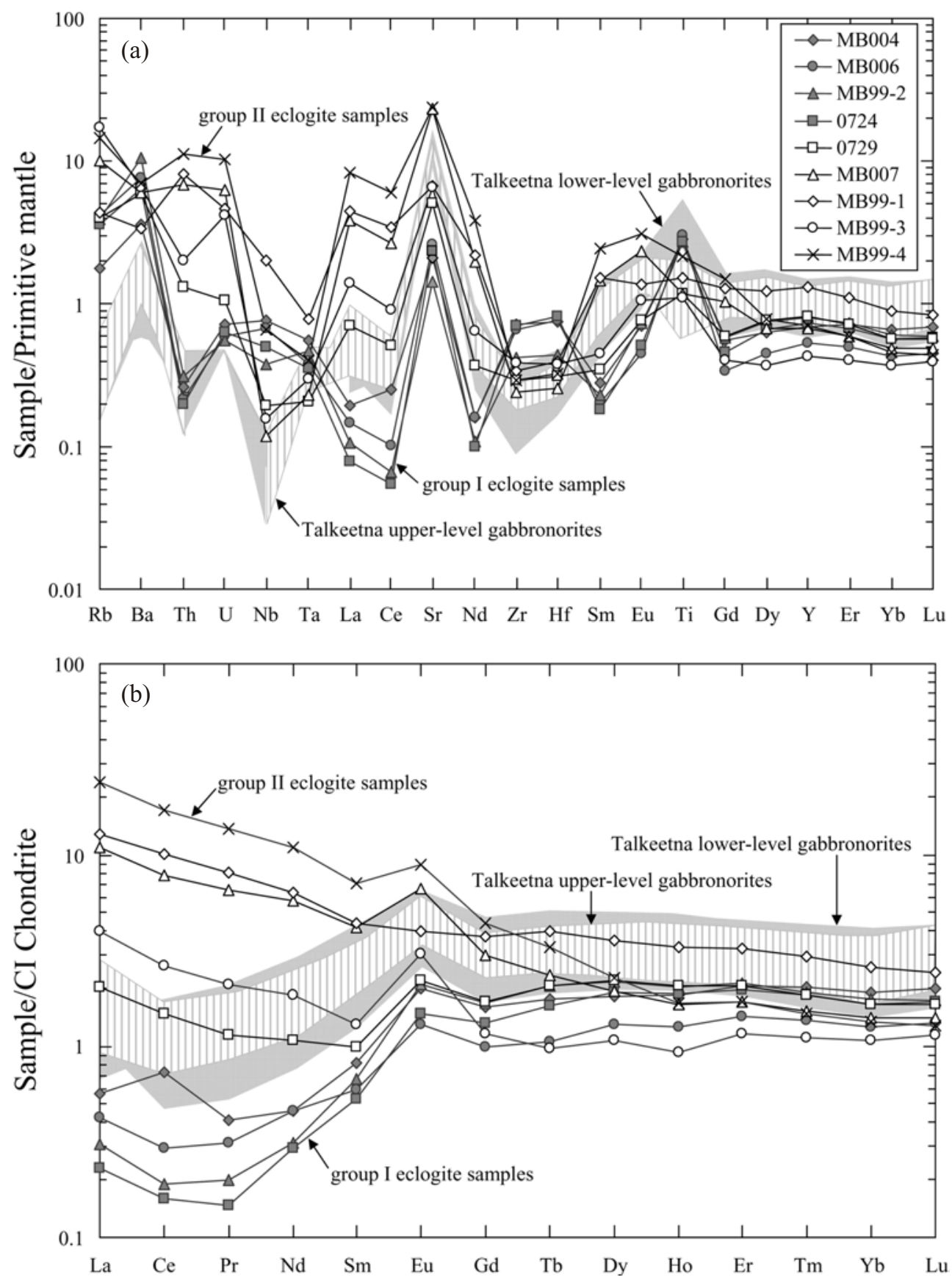

Fig. 5. Abundances of (a) trace elements and (b) REE normalized to (a) primitive mantle and (b) CI chondrite (Sun and McDonough 1989), then arranged in an order of increasing compatibility during mantle melting. The fields for the Talkeetna "upper-level" and "lower-level" gabbronorites are from Greene et al. (2006). 
Table 5. Sr and Nd isotopic compositions of the high-Al eclogite samples.

\begin{tabular}{|c|c|c|c|c|c|c|c|c|c|}
\hline & & ${ }^{87} \mathbf{R b} /{ }^{86} \mathrm{Sr}$ & ${ }^{87} \mathrm{Sr} /{ }^{86} \mathrm{Sr}$ & $\left({ }^{87} \mathrm{Sr} /{ }^{86} \mathrm{Sr}\right)_{220 \mathrm{Ma}}$ & ${ }^{147} \mathrm{Sm} /{ }^{144} \mathrm{Nd}$ & ${ }^{143} \mathrm{Nd} /{ }^{144} \mathrm{Nd}$ & $\left({ }^{143} \mathrm{Nd} /{ }^{144} \mathrm{Nd}\right)_{220 \mathrm{Ma}}$ & $\varepsilon_{\mathrm{Nd}}(0)^{\mathrm{a}} \varepsilon$ & $\mathrm{Nd}(220)$ \\
\hline \multirow{6}{*}{$\begin{array}{l}\text { group I } \\
\text { eclogite } \\
\text { samples }\end{array}$} & MB004 & 0.0732 & $0.704789 \pm 17^{b}$ & 0.704560 & 0.3520 & $0.512613 \pm 14^{\mathrm{c}}$ & 0.512106 & $-0.5^{\mathrm{d}}$ & -4.8 \\
\hline & & & & & & $0.512613 \pm 12^{\mathrm{d}}$ & 0.512106 & -0.5 & -4.8 \\
\hline & MB006 & 0.1403 & $0.705018 \pm 13$ & 0.704579 & 0.2555 & $0.512566 \pm 13^{\mathrm{c}}$ & 0.512198 & -1.4 & -3.1 \\
\hline & & & & & & $0.512595 \pm 06^{\mathrm{d}}$ & 0.512227 & -0.8 & -2.5 \\
\hline & MB99-2 & 0.2397 & $0.705665 \pm 14^{\mathrm{e}}$ & 0.704914 & 0.4274 & $0.512791 \pm 09^{\mathrm{c}}$ & 0.512176 & 3.0 & -3.5 \\
\hline & 0724 & 0.1327 & $0.704990 \pm 26^{\mathrm{e}}$ & 0.704575 & 0.3593 & $0.512733 \pm 13^{\mathrm{c}}$ & 0.512216 & 1.9 & -2.7 \\
\hline \multirow{10}{*}{$\begin{array}{l}\text { group II } \\
\text { eclogite } \\
\text { samples }\end{array}$} & 0729 & 0.0688 & $0.704871 \pm 11^{\mathrm{e}}$ & 0.704656 & 0.1837 & $0.512468 \pm 11^{\mathrm{c}}$ & 0.512203 & -3.3 & -3.0 \\
\hline & & & & & & $0.512459 \pm 08^{\mathrm{d}}$ & 0.512194 & -3.5 & -3.1 \\
\hline & MB007 & 0.0372 & $0.704693 \pm 16^{\mathrm{e}}$ & 0.704576 & 0.1458 & $0.512394 \pm 12^{\mathrm{c}}$ & 0.512184 & -4.8 & -3.3 \\
\hline & & & & & & $0.512395 \pm 09^{\mathrm{d}}$ & 0.512185 & -4.7 & -3.3 \\
\hline & MB99-1 & 0.0574 & $0.705001 \pm 12^{\mathrm{e}}$ & 0.704822 & 0.1361 & $0.512291 \pm 12^{\mathrm{c}}$ & 0.512095 & -6.8 & -5.1 \\
\hline & & & & & & $0.512292 \pm 06^{\mathrm{d}}$ & 0.512096 & -6.7 & -5.0 \\
\hline & MB99-3 & 0.2280 & $0.705221 \pm 26^{\mathrm{e}}$ & 0.704507 & 0.1395 & $0.512405 \pm 12^{c}$ & 0.512204 & -4.5 & -2.9 \\
\hline & & & & & & $0.512385 \pm 10^{\mathrm{d}}$ & 0.512184 & -4.9 & -3.3 \\
\hline & MB99-4 & 0.0541 & $0.704757 \pm 03^{\mathrm{e}}$ & 0.704588 & 0.1278 & $0.512287 \pm 11^{\mathrm{c}}$ & 0.512103 & -6.8 & -4.9 \\
\hline & & & & & & $0.512308 \pm 07^{d}$ & 0.512124 & -6.4 & -4.5 \\
\hline
\end{tabular}

Note: ${ }^{a}{ }^{143} \mathrm{Nd} / 144 \mathrm{Nd}=0.512638$ and ${ }^{147} \mathrm{Sm} /{ }^{144} \mathrm{Nd}=0.1960$ for CHUR were used to calculate $\varepsilon_{\mathrm{Nd}}$.

${ }^{b}$ The uncertainty is $2 \sigma$.

${ }^{c}$ Nd isotopic ratios measured by MAT262.

${ }^{d}$ Nd isotopic ratios determined by TRITON TI.

' mean values from three analyses on MAT262, for which the external errors are reported.

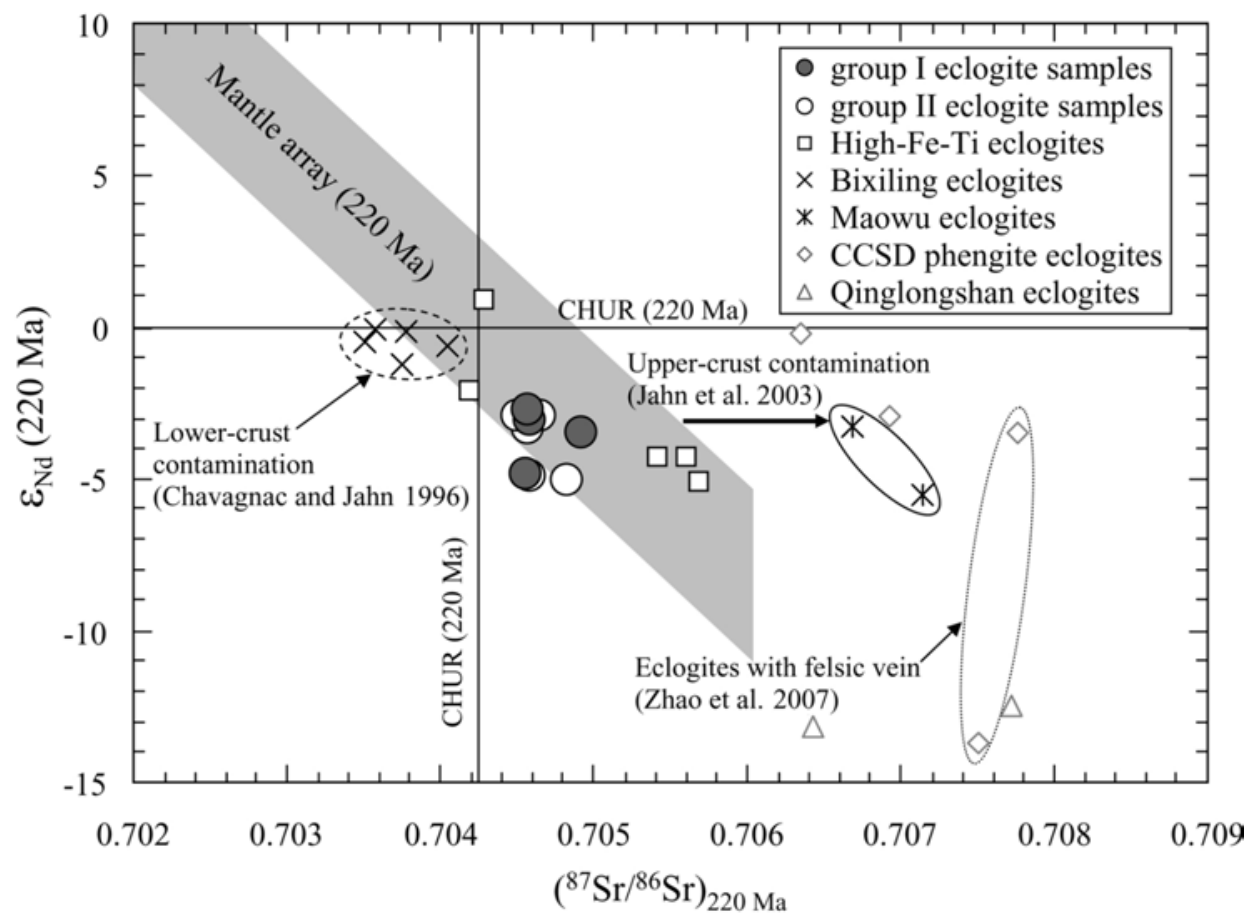

Fig. 6. Plot of $\varepsilon_{\mathrm{Nd}}(220 \mathrm{Ma})$ versus $\left({ }^{87} \mathrm{Sr} /{ }^{86} \mathrm{Sr}\right)_{220 \mathrm{Ma}}$ comparing the high-Al eclogite samples to other Dabie-Sulu eclogites. The high-Fe-Ti eclogites plot within the mantle array, representing protolith characteristics (Liu et al. 2007). Some Bixiling eclogites deviate from the mantle array to slightly lower $\varepsilon_{\mathrm{Nd}}(220 \mathrm{Ma})$ values, reflecting lower-crust contamination (Chavagnac and Jahn 1996). Maowu eclogites deviate to higher $\left({ }^{87} \mathrm{Sr} /{ }^{86} \mathrm{Sr}\right)_{220} \mathrm{Ma}$ values, indicating involvement of upper-crust component (Jahn et al. 2003). The low $\varepsilon_{\mathrm{Nd}}(220 \mathrm{Ma})$ and high $\left({ }^{87} \mathrm{Sr}{ }^{86} \mathrm{Sr}\right)_{220 \mathrm{Ma}} \mathrm{values}$ of the Qinglongshan eclogites were inherited from continental flood basalt (Jahn 1998). 
response to decreasing P-T, the high-pressure fluids could precipitate kyanite, zoisite, paragonite, quartz, phengite, omphacite, glaucophane, garnet, rutile, and zircon. These are typical constituent minerals of veins in eclogites (e.g., Holland 1979; Becker et al. 1999; Rubatto and Hermann 2003; Spandler and Hermann 2006). In the Tauern Window eclogites, the kyanite-containing veins coexist with kyanite and zoisite porphyroblasts (Holland 1979). Although the kyanite-containing veins are absent from our samples, the occurrence of zoisite porphyroblasts confirms the role of high-pressure fluids. It is proposed that the initial stage of garnet-fluid interaction produced the irregular $\mathrm{Ky}_{\mathrm{II}}$ networks, which gradually developed into $\mathrm{Ky}_{\text {II }}$ porphyroblasts of up to $\sim 9 \mathrm{~mm}$ by continuous kyanite crystallization and garnet consumption (Figs. 2c - d). In this scenario, garnet could provide $\mathrm{Si}$ and $\mathrm{Al}$ for $\mathrm{Ky}_{\mathrm{II}}$ crystallization, and the absence of quartz might reflect relatively higher solubility of Si compared to $\mathrm{Al}$ at the P-T conditions (e.g., Manning 2004; John et al. 2008).

Lacking relevant thermobarometers, the P-T conditions for kyanite crystallization can only be inferred from petrographic textures. Because the $\mathrm{Ky}_{\mathrm{I}}$ grains are in apparent textural equilibrium with garnet and omphacite, it is inferred that they formed during peak metamorphism. In contrast, $\mathrm{Ky}_{\mathrm{II}}$ encloses peak garnet and omphacite, implying formation during retrogression. Similarly, three lines of evidence indicate that zoisite porphyroblasts are also of retrograde origin. They are: (1) relatively low $\mathrm{P}$ and $\mathrm{T}$ for the zoisite formation reaction calculated from THERMOCALC (reaction 1), (2) relatively low $\mathrm{Si}$ contents of phengite inclusions in zoisite (Table 2; Carswell and Harley 1990), and (3) the texture of zoisite porphyroblasts enclosing $\mathrm{Ky}_{\mathrm{I}}$, garnet and omphacite (Fig. 2e). If evolved along the P-T path for most Sulu eclogites, the zoisite formation reaction (1) occurred at $\sim 750^{\circ} \mathrm{C}$ and $17 \mathrm{kbar}$ (Fig. 3). The paragenetic sequence of zoisite and $\mathrm{Ky}_{\mathrm{II}}$, however, cannot be unambiguously determined, because intergrowth relationship between these two minerals is not observed.

\subsection{Protolith Characteristics}

A common approach for revealing the geochemical evolution at convergent margins is to compare the compositions of eclogites to that of their protoliths (e.g., Becker et al. 2000). Nd isotope ratio and abundances of immobile elements are usually used to evaluate the nature of the protoliths (Jahn 1998, 1999; Liu et al. 2007). Similar to many other eclogites from the Sulu metamorphic terrane, the samples have $\varepsilon_{\mathrm{Nd}}$ values ranging from -5.1 to -2.5 , indicating continental rather than oceanic protoliths (Fig. 6; Jahn 1998, 1999). The low HREE abundances of $1-2$ times of the chondritic values require mafic cumulate protoliths, such as gabbros, gabbronorites, and troctolites. These protoliths cannot be readily distinguished using major oxide contents because $\mathrm{Si}, \mathrm{Al}, \mathrm{Ca}$, and $\mathrm{Na}$ are subjected to metamorphic modification and the concentrations of relatively immobile Fe and Mg (Becker et al. 1999; Manning 2004; John et al. $2008)$ are similar in these protoliths. The systematic variations between major oxide abundances, however, provide clues to the nature of cumulate protoliths. The well-defined inverse $\mathrm{SiO}_{2}-\mathrm{Al}_{2} \mathrm{O}_{3}$ and $\mathrm{Al}_{2} \mathrm{O}_{3}-\mathrm{CaO}$ correlations of the samples contradict the positive trends formed by mixing cumulative olivine and plagioclase and are not the characteristics of gabbros (Fig. 4). Therefore, they reflect the control of metamorphism instead of protolith characteristics. The three samples with highest $\mathrm{Al}$ abundances are plotted out of the fields of mafic cumulates (Fig. 4). They are obviously not representatives of protolith compositions. Three samples having $\sim 25 \% \mathrm{Al}_{2} \mathrm{O}_{3}$ are plotted in the troctolite field (Fig. 4). However, their low Ni contents of $<200 \mathrm{ppm}$ are not the characteristics of troctolites. As indicated by the high $D_{N i}^{\text {eclogite/fluid }}$ values of $>124$ (Green and Adam 2003) and low $\mathrm{Ni}$ contents in eclogite veins (Zhang et al. 2008), Ni is immobile during eclogite-fluid interaction. Composed of $\sim 20$ - $40 \%$ cumulate olivine $\left(\sim \mathrm{Fo}_{80}\right)$, most troctolites contain $>400$ ppm Ni (Benoit et al. 1996; Turner 1996; Lissenberg et al. 2005). The relatively low Ni contents of $<285 \mathrm{ppm}$ in the samples require $<20 \%$ olivine in the protoliths; therefore, gabbro or gabbronorite or norite protoliths are favored over the troctolite protoliths. Three samples with $\mathrm{Al}_{2} \mathrm{O}_{3}$ contents lower than $22 \%$ are better compositional representatives for the protoliths. Their major oxide abundances are further considered to better constrain the protolith composition.

Proportions of constituent minerals in cumulate protoliths can be estimated by balancing compositions of the cumulate minerals against bulk eclogite compositions, which are (nearly) free from metamorphic modifications. Although this approach ignores variations in mineral compositions, Liu et al. (2007) successfully used it to constrain mineral proportions of the protoliths of Sulu high Fe-Ti eclogites. In our mass balance calculations, six sets of mineral compositions varying from strongly mafic $\left(\mathrm{Fo}_{90}-\mathrm{An}_{90}-\mathrm{En}_{80}\right)$ to moderately mafic $\left(\mathrm{Fo}_{80}-\mathrm{An}_{80}-\mathrm{En}_{71}\right)$ to weakly mafic $\left(\mathrm{Fo}_{70^{-}}-\mathrm{An}_{70^{-}}\right.$ $\mathrm{En}_{60}$ ) were balanced against the bulk compositions of three low-Al samples, MB006, MB004, and 0724. Based on mafic cumulates from Talkeetna (Greene et al. 2006), clinopyroxene composition is kept unchanged with a $\mathrm{Mg} \#$ of 77 $\left(\mathrm{Cpx}_{2}\right.$ in Table 6) for all mineral assemblages, except for the value of $86\left(\mathrm{Cpx}_{1}\right.$ in Table 6$)$ for the strongly mafic assemblage. For a given mineral assemblage, balancing against the composition of MB006 always results in higher sum of squared residuals $\left(\Sigma R^{2}\right)$ of $10-16$, which mostly reflects the discrepancies between modeled and observed $\mathrm{Na}_{2} \mathrm{O}$ contents. The relatively high $\mathrm{Na}_{2} \mathrm{O}$ content of $3.66 \%$ in sample MB006 is not typical for gabbro but reflects its high omphacite proportion of $62 \%$. Omphacite enrichment could be a consequence from mineral segregation in response to ductile deformation or from interacting with high-pressure flu- 
Table 6. The results of mass balance using unweighted least squared regression.

\begin{tabular}{|c|c|c|c|c|c|c|c|c|c|c|c|c|c|c|c|c|c|c|c|c|c|}
\hline & \multirow[b]{2}{*}{ MB006 } & \multicolumn{6}{|c|}{$\begin{array}{l}\text { hypothetical mineral } \\
\text { assemblages }\end{array}$} & \multicolumn{7}{|c|}{$\begin{array}{l}\text { hypothetical mineral } \\
\text { assemblages }\end{array}$} & \multicolumn{7}{|c|}{$\begin{array}{l}\text { hypothetical mineral } \\
\text { assemblages }\end{array}$} \\
\hline & & 1 & 2 & 3 & 4 & 5 & 6 & MB004 & 1 & 2 & 3 & 4 & 5 & 6 & 0724 & 1 & 2 & 3 & 4 & 5 & 6 \\
\hline $\mathrm{SiO}_{2}$ & 49.5 & 49.2 & 49.2 & 49.3 & 49.2 & 49.0 & 49.0 & 45.0 & 45.8 & 45.7 & 45.8 & 45.6 & 45.3 & 45.1 & 45.9 & 46.4 & 46.3 & 46.4 & 46.1 & 46.0 & 45.9 \\
\hline $\mathrm{Al}_{2} \mathrm{O}_{3}$ & 18.4 & 20.7 & 20.7 & 20.7 & 20.8 & 21.4 & 21.8 & 21.7 & 21.3 & 21.3 & 21.3 & 21.6 & 22.0 & 22.4 & 22.4 & 22.4 & 22.4 & 22.4 & 22.7 & 23.1 & 23.4 \\
\hline $\mathrm{CaO}$ & 13.0 & 13.1 & 13.2 & 13.1 & 13.4 & 13.6 & 13.8 & 11.6 & 10.6 & 10.8 & 10.6 & 10.9 & 11.0 & 11.2 & 12.0 & 11.4 & 11.6 & 11.4 & 11.7 & 11.8 & 11.9 \\
\hline $\mathrm{MgO}$ & 10.0 & 10.3 & 10.0 & 10.1 & 9.90 & 9.75 & 9.59 & 11.3 & 11.3 & 11.5 & 11.5 & 11.7 & 11.7 & 11.6 & 10.1 & 10.1 & 10.2 & 10.3 & 10.3 & 10.3 & 10.2 \\
\hline $\mathrm{FeO}$ & 4.82 & 4.72 & 5.55 & 5.13 & 5.76 & 6.02 & 6.10 & 7.86 & 4.56 & 5.39 & 4.96 & 5.98 & 6.76 & 7.30 & 6.27 & 4.27 & 4.96 & 4.50 & 5.37 & 5.90 & 6.22 \\
\hline $\mathrm{Na}_{2} \mathrm{O}$ & 3.66 & 0.65 & 1.05 & 1.42 & 1.43 & 1.89 & 2.37 & 1.90 & 0.64 & 1.04 & 1.43 & 1.46 & 1.92 & 2.43 & 2.61 & 0.68 & 1.10 & 1.51 & 1.53 & 2.02 & 2.54 \\
\hline \multirow[t]{2}{*}{$\Sigma \mathrm{R}^{2}$} & & 14.7 & 12.7 & 10.4 & 11.7 & 14.1 & 15.8 & & 14.3 & 8.17 & 10.5 & 4.6 & 1.85 & 1.31 & & 8.27 & 4.32 & 4.94 & 2.25 & 1.01 & 1.10 \\
\hline & & \multicolumn{6}{|c|}{$\begin{array}{l}\text { calculated mineral proportions } \\
\text { in the protolith of } \mathrm{MB} 006\end{array}$} & & \multicolumn{6}{|c|}{$\begin{array}{l}\text { calculated mineral proportions } \\
\text { in the protolith of } \mathrm{MB004}\end{array}$} & & \multicolumn{6}{|c|}{$\begin{array}{c}\text { calculated mineral proportions } \\
\text { in the protolith } \\
\text { of } 0724\end{array}$} \\
\hline Plag\% & & 52.1 & 58.6 & 60.3 & 60.4 & 64.3 & 67.7 & & 56.1 & 61.3 & 62.9 & 64.1 & 67.4 & 70.8 & & 59.2 & 64.5 & 66.3 & 67.2 & 70.6 & 74.1 \\
\hline Сpx\% & & 14.1 & 13.1 & 13.9 & 14.8 & 16.3 & 18.2 & & 0.5 & 0.3 & 1.2 & 1.6 & 3.1 & 5.2 & & 1.7 & 1.3 & 2.3 & 2.7 & 4.4 & 6.4 \\
\hline Opx\% & & 37.8 & 24.4 & 18.9 & 16.3 & 4.7 & -8.1 & & 35.5 & 21.4 & 15.7 & 9.9 & -2.7 & -17.7 & & 34.3 & 20.6 & 14.5 & 9.9 & -2.7 & -17.1 \\
\hline $\mathrm{Ol} \%$ & & -5.6 & 3.5 & 6.6 & 9.1 & 16.5 & 24.8 & & 1.9 & 12.4 & 15.6 & 21.6 & 30.8 & 41.4 & & -0.1 & 9.8 & 13.2 & 17.9 & 26.7 & 36.6 \\
\hline
\end{tabular}

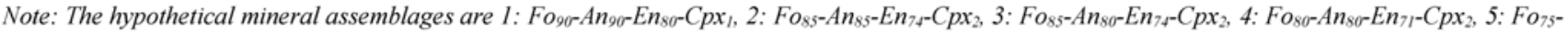
$A n_{75}-E n_{65}-C p x_{2}$, and 6: $F_{070}-A n_{70}-E n_{60} C p x_{2}$. Compositions of $C p x_{1}$ and $C p x_{2}$ are from Talkeetna arc section, Alaska (Greene et al. 2006). Their Mg\# are 86 and 77 , respectively.

ids. Both possibilities indicate metamorphic modification. For a given set of mineral compositions, mineral proportions calculated from the compositions of samples MB004 and 0724 are similar with the lowest $\Sigma \mathrm{R}^{2}$ values from sample 0724. The absence of banded textures in these two samples also implies minimum extents of mineral segregation. Although low $\Sigma \mathrm{R}^{2}$ value of $<2$ are obtained from weakly mafic assemblages, the resulting mineral proportions are not reasonable; specifically, negative proportion values for orthopyroxene and $>20 \%$ olivine. The latter is inconsistent with the low Ni contents of the samples. The best fit is represented by a $\Sigma \mathrm{R}^{2}$ of 2.25 from balancing the compositions of moderate mafic assemblage and the bulk composition of 0724. The resulting plagioclase, orthopyroxene, clinopyroxene, and olivine proportions are $67 \%, 10 \%, 3 \%$, and $18 \%$, respectively. Such olivine gabbronorites usually occur on the ultramafic to mafic transition in a layered intrusion (e.g., Mathison and Hamlyn 1987; Latypov et al. 2007).

\subsection{Metamorphic Modifications on Bulk Compositions}

Being mixtures of several cumulus and intercumulus phases, gabbroic rocks do not show systematic variations in the $\mathrm{SiO}_{2}-\mathrm{Al}_{2} \mathrm{O}_{3}-\mathrm{CaO}-\mathrm{MgO}$ space as indicated by the compilation of Greene et al. (2006) and Liu et al. (2007). Therefore, the inverse $\mathrm{SiO}_{2}-\mathrm{Al}_{2} \mathrm{O}_{3}$ and $\mathrm{Al}_{2} \mathrm{O}_{3}-\mathrm{CaO}$ correlations of the samples must be resulted from metamorphic processes (Fig. 4). They can be explained by Al-enrichment accompanied with Si-Ca-losses or Al-loss with Si-Ca-enrichments during interaction with high-pressure fluids. Mineral segregation as exemplified by the garnetite (Jahn 1998) can also affect major element distribution in the protoliths. Although not as extreme as garnetite, two group I samples, MB99-2 and MB006, show banded texture of alternating garnet-rich and omphacite-rich layers with garnet/omphacite ratios of 3.4 and 0.51 , respectively (Table 1). The low $\mathrm{SiO}_{2}(41.9 \%$ ), high $\mathrm{Al}_{2} \mathrm{O}_{3}(28.6 \%)$ and $\mathrm{MgO}(9.16 \%)$ contents in sample MB99-2 (Figs. 7a, c) are consistent with garnet enrichment resulted from mineral segregation during metamorphism. Similarly, the high $\mathrm{Na}_{2} \mathrm{O}(3.66 \%)$ and $\mathrm{MgO}(10.0 \%)$ in sample MB006 (Fig. 7f) is not the characteristic of gabbroic cumulates but reflects the role of omphacite. Sample MB006 also has the lowest HREE abundances, consistent with its low garnet/omphacite ratio of 0.51 (Table 1). Metamorphic mineral segregation might be initiated or enhanced by fluid introduction. Other samples with garnet/ omphacite ratios varying from 0.78 to 1.81 were subjected to lesser extents of mineral segregation and fluid infiltration.

The garnet-rich MB99-2, omphacite-rich MB006, and other group I samples show similar trace element variation patterns, except for the slightly lower HREE abundances of MB006 (Fig. 5). This feature is also observed for the group 

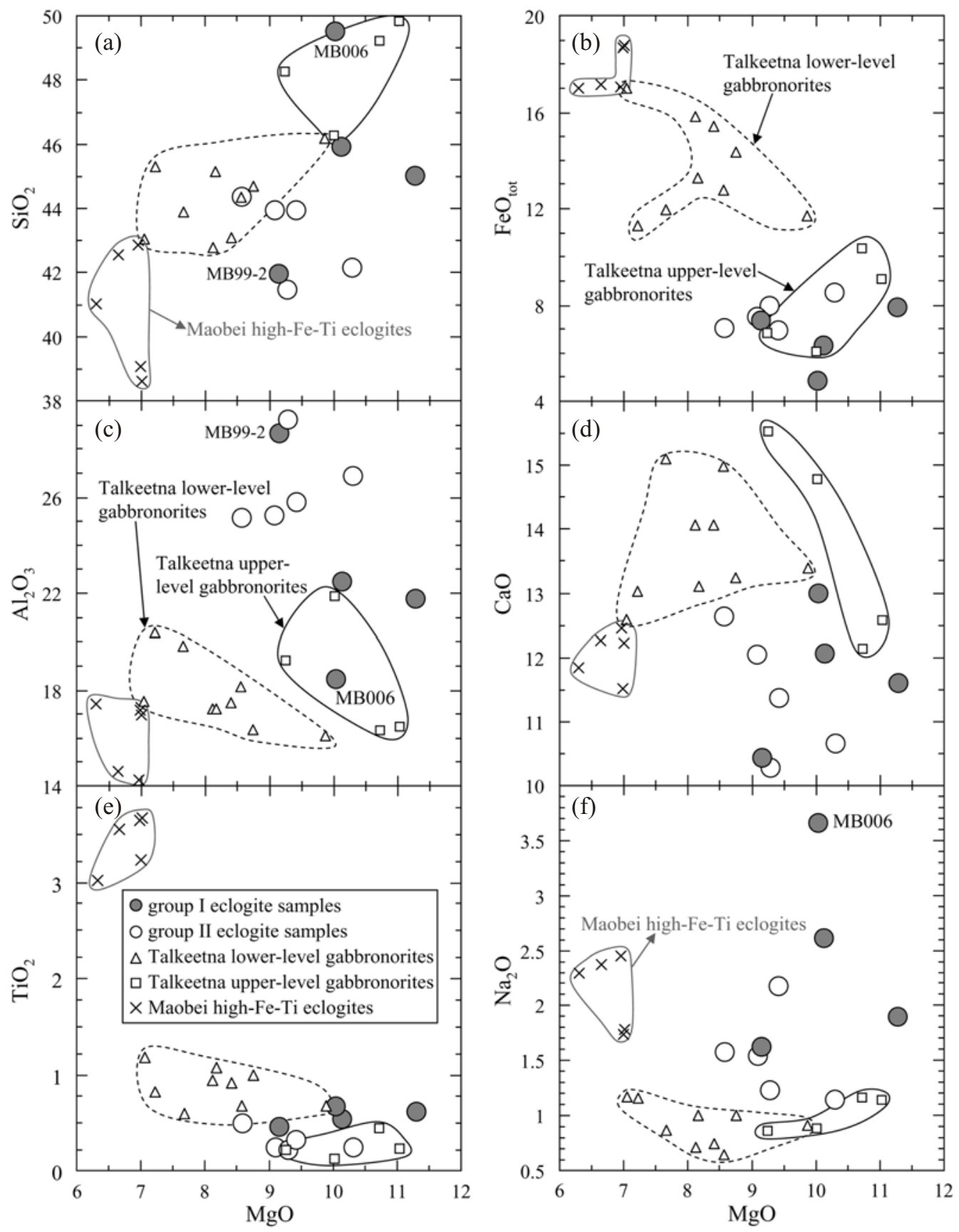

Fig. 7. $\mathrm{MgO}$ variation diagrams comparing the high-Al eclogite samples, Maobei high-Fe-Ti eclogites (Liu et al. 2007), and the Talkeetna upper- and lower-level gabbronorites (Greene et al. 2006).

II samples, despite of the variations in their garnet/omphacite ratio. Consequently, the differences in trace element variation patterns between the two sample groups are not controlled by metamorphic segregation but reflect protolith characteristics and/or the effects of eclogite-fluid interaction. Mobility of elements in high-pressure fluids controls the extent of metamorphic modification on protolith compositions. It has been established that LILE and LREE are relatively mobile than HREE and HFSE (e.g., Hermann et al. 2006; John et al. 2008). Although Gao et al. (2007) modeled $\sim 65 \%$ HREE loss for few Tianshan eclogites that were subjected to relatively larger volumes of high-pressure fluids, HREE are generally immobile during HP/UHP metamorphism (e.g., Becker et al. 1999, 2000; John et al. 2004; Zhao et al. 2007). In contrast, HFSE behave complicatedly; immobile in some metamorphic suites (e.g., Becker et al. 1999, 2000; John et al. 2004), but mobile from centimeters to several tens of meters in others (Franz et al. 2001; Rubatto and Hermann 2003; Gao et al. 2007). These constraints provide a basis for elucidating the possible protolith-process 
combinations to explain the trace element variations in the samples.

The HREE and Zr contents of the eclogite samples and arc gabbros/gabbronorites are comparable but lower than that of the mafic cumulates at intra-plate settings, even when
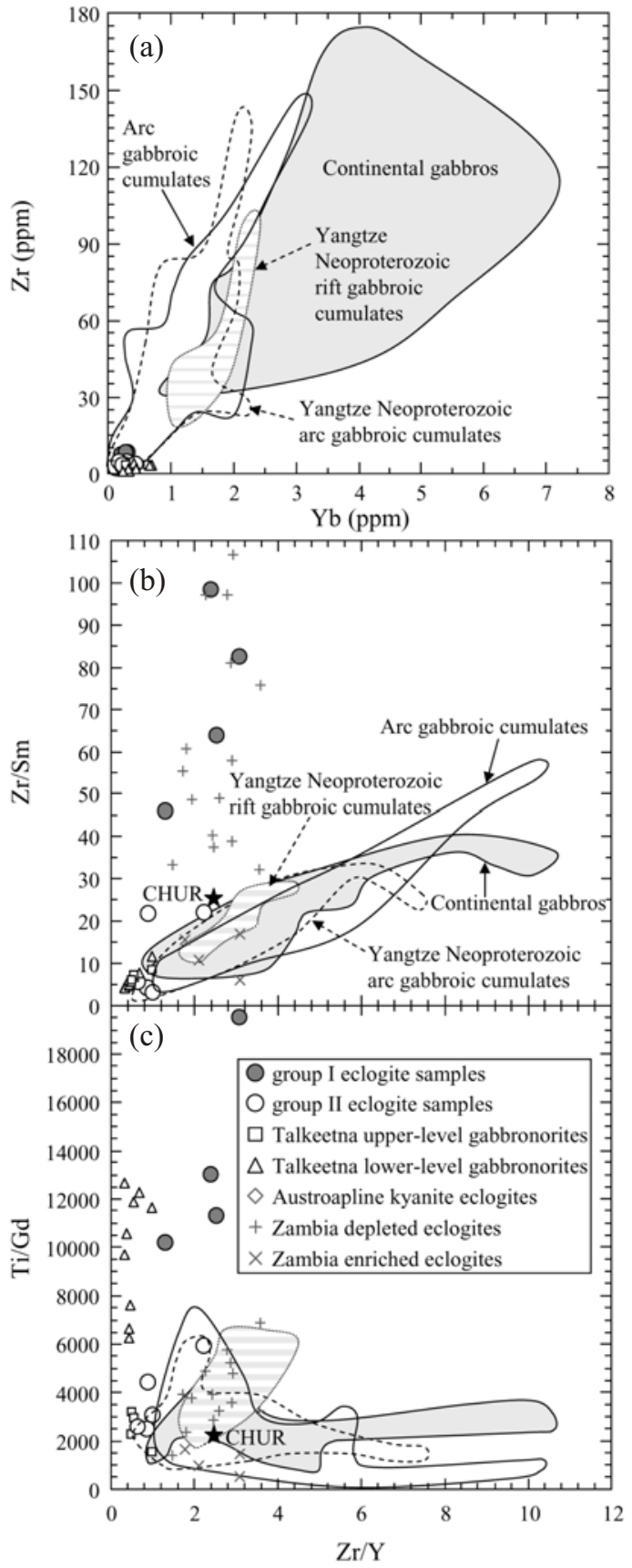

a $65 \%$ loss is considered for the samples (Gao et al. 2007; Fig. 8a). The low HREE contents in arc cumulates were inherited from arc lavas, which were derived from residual mantle after MORB extraction. However, the HFSE-enrichments in the group I samples (Fig. 5a) do not coincide with

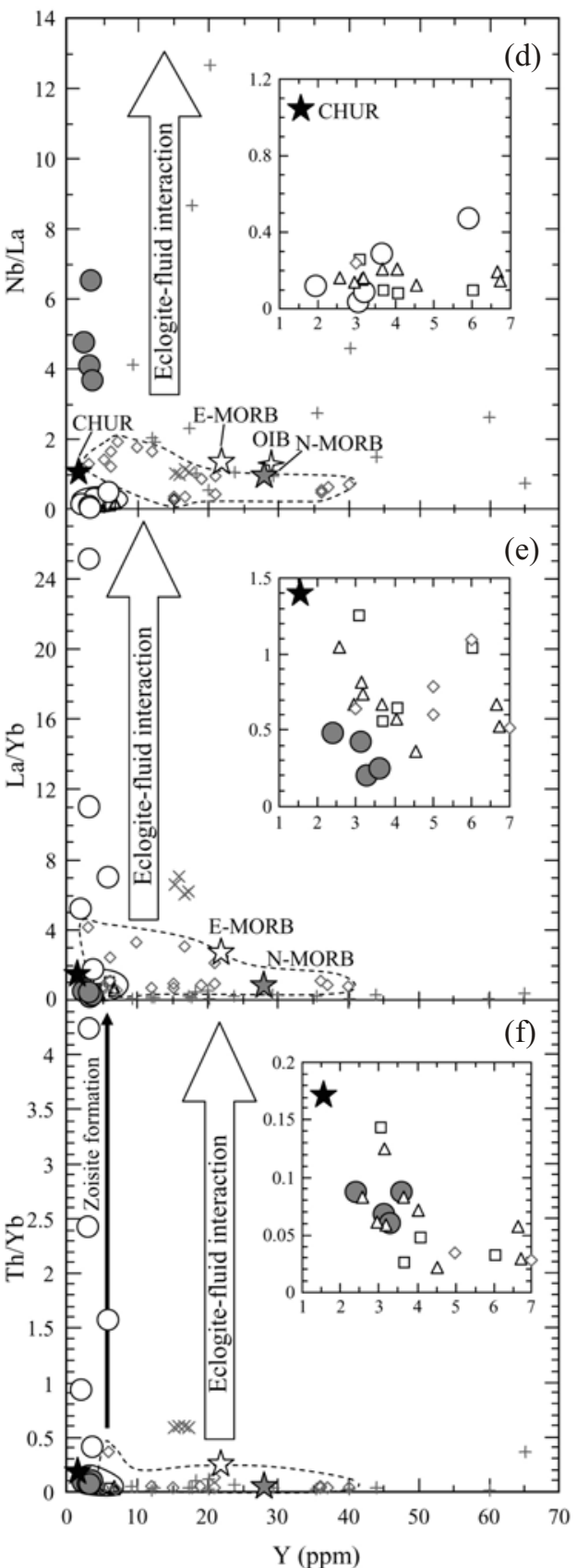

Fig. 8. (a) Abundance of $\mathrm{Zr}$ versus $\mathrm{Yb}$ content showing that the low $\mathrm{Zr}$ and $\mathrm{Yb}$ concentrations of the high-Al eclogite samples are distinct from that of continental gabbroic cumulates (Liu et al. 2007 and referred therein) but similar to that of the arc cumulates (Sisson et al. 1996; Zhou et al. 2002, 2006; Ling et al. 2003; Claeson and Meurer 2004; Greene et al. 2006). Zr/Y versus (b) Zr/Sm and (c) Ti/Gd plots comparing the high-Al eclogite samples, Zambia eclogites (John et al. 2004), Austroapline kyanite eclogites (Sassi et al. 2004), and Talkeetna upper- and lower-level gabbronorites (Greene et al. 2006). Also shown are fields for the Yangtze Neoproterozoic rift and arc cumulates (Zhou et al. 2002, 2006; Ling et al. 2003), continental gabbros (Liu et al. 2007 and referred therein) and other arc cumulates (Sisson et al. 1996; Claeson and Meurer 2004). (d) - (f) Abundance of Y versus Nb/La, $\mathrm{La} / \mathrm{Yb}$, and $\mathrm{Th} / \mathrm{Yb}$ ratios comparing the samples to CHUR, N-MORB, E-MORB, and OIB of Sun and McDonough (1989). The element fractionations in the samples are explained by interaction with high-pressure fluids. 
most magmatic mafic cumulates for their high $\mathrm{Zr} / \mathrm{Sm}, \mathrm{Ti} / \mathrm{Gd}$, and $\mathrm{Nb} /$ La ratios (Figs. $8 \mathrm{~b}$ - d). Although similarly high Ti/Gd ratios also occur in the Talkeetna "lower level" gabbronorites, a typical section of plagioclase-rich cumulates from the arc environments, these gabbronorites differ from the group I samples for the lower $\mathrm{Zr} / \mathrm{Sm}$ and $\mathrm{Zr} / \mathrm{Y}$ values (Greene et al. 2006; Fig. 8b). Therefore, the HFSE enrichments in the group I samples are not protolith characteristics but reflect metamorphic modifications. The superchondritic $\mathrm{Zr} / \mathrm{Sm}$ and $\mathrm{Nb} / \mathrm{La}$ ratios from a subgroup of Zambia eclogites were explained by LILE and LREE removal by dehydration while HFSE remained intact (John et al. 2004; Figs. 8b, d). This process, however, does not result in the high $[\mathrm{Ti} / \mathrm{HREE}]_{\mathrm{ch}}$ ratios of the group I samples (Fig. 8c). Consequently, metamorphic addition of HFSE must be considered for the HFSE-enrichments in the group I samples. Experiments showed that $\mathrm{F}$ - and Na-Al-Si polymers in highpressure fluids enhanced rutile solubility (e.g., Audétat and Keppler 2005). The occurrence of rutile and zircon in eclogitic veins confirms that HFSE were transported via fluids (e.g., Franz et al. 2001; Rubatto and Hermann 2003). Although eclogite facies veins are not observed in hand specimen, clusters of smaller rutile inclusions (10 - 50 $\mu \mathrm{m}$, mostly $<20 \mu \mathrm{m}$ ) concur with epidote along annealed fractures in garnet and omphacite (Fig. 2f), implying crystallization from fluid infiltration. The high $\mathrm{CaO}$ content of $\sim 0.5 \%$ in some of these small rutile inclusions is not the characteristic of the larger interstitial rutile $(0.05-0.7 \mathrm{~mm})$, possibly reflecting fluid infiltration that resulted in the superchondritic $\mathrm{Nb} / \mathrm{La}$ and Ti/HREE ratios. Similarly, the positive $\mathrm{Zr}$ and Hf anomalies (Fig. 5a) can be explained by zircon crystallization facilitated by interaction with high-pressure fluids (Williams et al. 1996; Dempster et al. 2008). This HFSE enrichment mechanism might also operate in other eclogites; however, its chemical consequences are obscured by relatively higher HFSE concentrations in protoliths.

In contrast to the HFSE enrichments and LREE depletions of the group I samples, the group II samples are characterized by HFSE depletions with LREE enrichments (Fig. 5a). Their Ti/HREE and $\mathrm{Zr} / \mathrm{Y}$ ratios are comparable to that of the arc mafic cumulates and most similar to that of the Talkeetna "upper level" gabbronorites (Figs. 8b, c). There is a surprising match in the trace element variation patterns of these Talkeetna "upper-level" gabbronorites and a group II sample, 0729, which has the lowest zoisite proportion (Fig. 5). Other group II samples have higher LILE and LREE contents (Figs. 5a and $8 \mathrm{e}-\mathrm{f}$ ), indicating metamorphic enrichments.

In summary, major element compositions of the studied eclogites were controlled by mineral segregation and, to a less extent, by fluid infiltration. In contrast, trace element distribution was dominated by eclogite-fluid interaction that resulted in HFSE-enrichments in the group I samples and LILE-LREE enrichments in the group II samples. These results show that even $\mathrm{Zr} / \mathrm{Sm}$ and $\mathrm{Ti} / \mathrm{Eu}$ ratios are not reliable protolith tracers. For a suite of metamorphic rocks, critically evaluating their compositional systematics and petrographic textures are required to infer the nature of protoliths.

\subsection{Implications on Element Fractionations in Eclogites}

Studies on the compositions of eclogites having an oceanic affinity have documented various extents of element fractionations from isochemical metamorphism (Chalot-Prat et al. 2003; Miller et al. 2007) to LREE-MREE removal without changes on the HREE and HFSE budgets (John et al. 2004) to $<10-20 \%$ loss for HFSE and HREE (Becker et al. 2000). In contrast, chemical consequences from subduction and exhumation of rocks with a continental affinity have not been as intensively investigated. Lower extents of element fractionation might be predicted from low water content in continental crust due to aerial exposure. Rapid subduction during the prograde metamorphism in the Dabie-Sulu terrane also prevented devolatilization (summarized by Zheng et al. 2003). However, the occurrences of eclogite facies veins and fluid inclusions in the Sulu metamorphic terrane confirm the existence of fluids (Chen et al. 2007; Zhang et al. 2008). Also, garnet and omphacite in the Sulu eclogites contain respectively $522-1584$ and $1170-20745$ ppm of water with $\sim 100-400 \mathrm{ppm}$ of structural hydroxyl (Chen et al. 2007). Such significant amounts of water could be liberated when metamorphic temperature reached maximum at early exhumation (Fig. 3; Zheng et al. 2003; Chen et al. 2007). Consequently, these retrograde fluids might be released at higher pressures than prograde fluids. Therefore, they were more reactive for higher solubility on most rockconstituent elements, dominating the differences in trace element distribution between the groups I and II samples.

The occurrence of rutile and zircon in eclogitic veins from the Sulu metamorphic terrane (Zhang et al. 2008) confirms that HFSE were dissolved into and transported by the retrograde fluids. Based on the occurrence of clusters of secondary rutile inclusions along the fractures, it is proposed that the dissolved HFSE were precipitated after short migration distance forming the positive HFSE anomalies in the group I samples (Fig. 5a). The U-shaped REE patterns of the group I samples (Fig. 5b) require that small amounts of LREE were also incorporated into eclogite constituent minerals. Subsequently, the fluids became relatively enriched in LILE and, to lesser extents, LREE. They were transported for longer distances then precipitated into the group II samples, resulting in higher LREE/HREE, REE/HFSE, and LILE/REE ratios (Fig. 8). In this model, the groups I and II eclogite samples were subjected to a common fluid whose composition evolved during interaction with eclogites and the observed HFSE-REE and HFSE-LILE fractionations were results of differences in element solubility and mobility in fluids. Alternatively, the compositional differences be- 
tween the two groups might reflect interacting with fluids of distinct origins. The first interpretation is favored because all samples have similar $\mathrm{Sr}$ and $\mathrm{Nd}$ isotope ratios (Fig. 6).

The interpretation of high-pressure fluids precipitating HFSE, LREE, and LILE into the eclogite samples implies that these elements were retained in the subducted continental lithosphere, although once released into high-pressure fluids. Similarly, nearly isochemical metamorphism was concluded for subduction and exhumation of most oceanic lithosphere (e.g., Becker et al. 1999, 2000; Chalot-Prat et al. 2003; Miller et al. 2007). Although some Zambia eclogites were LILE-LREE depleted by dehydration, they coexist with LREE and LILE enriched counter parts (John et al. 2004), indicating limited migration distances for these elements. Even the relatively long HFSE transport distance of 10 - 100 meters inferred from the Tianshan eclogites are minute compared to the thickness of the subducted lithosphere (Gao et al. 2007). The process of initial dissolution followed by prompt precipitation might not be limited to eclogitization but extend to most metamorphosed lithologies. Spandler et al. (2003) compared mineral trace-element data and bulk-rock data at different metamorphic grades to conclude that the elements released into fluids by mineral breakdown reactions are promptly incorporated into the newly-formed minerals. If there is no significant element loss, except for highly incompatible elements such as $\mathrm{Rb}$, $\mathrm{Cs}$, and $\mathrm{Ba}$, from subducted lithosphere to metamorphic fluids, the chemical flux to metasomatized mantle wedge must be mainly from the topmost part of subducted slabs; most likely subducted sediments as concluded from the correlation between compositions of sediment inputs and arc magmatism outputs (Plank and Langmuir 1993; Elliott 2003).

\section{CONCLUSIONS}

Petrographic textures and compositional variations of the high-Al eclogites from the Sulu metamorphic terrane all reflect the role of high-pressure fluids. Distinct from the inclusion-free kyanite grains, kyanite networks and kyanite grains containing anhedral garnet-omphacite inclusions crystallized at the expense of garnet and omphacite during eclogite-fluid interaction. The occurrence of zoisite porphyroblasts strengthens the role of fluids. Low HREE concentrations are common to all the samples and require derivation from arc cumulates. Comparison to mafic cumulates shows that high $\mathrm{Al}$ concentrations of $>22 \%$ are results from metamorphic modification whereas low-Al samples are compositionally better representative of protolith. An olivine gabbronorite protolith is inferred from mass balance between the bulk compositions of low-Al samples and hypothetical cumulate mineral compositions. The intensive HFSEREE fractionations between the groups I and II samples are explained by difference in element mobility during eclogitefluid interaction. The model involves dissolution of LREE,
LILE, and HFSE into fluids released during initial stage of retrogression at $>750^{\circ} \mathrm{C}$. HFSE precipitated promptly after a short migration distance forming clusters of small rutile grains along annealed fractures in the group I samples. HFSE precipitation also partially contributed to the crystallization of interstitial zircon. Migrating further away from the HFSE sinks, the fluids then deposited LREE and LILE into newly-formed zoisite in the group II eclogites, resulting in the observed HFSE-REE and HFSE-LILE fractionations. This model requires limited transport distances for elements in high-pressure fluids. If so, chemical contributions to mantle wedges from subducted lithosphere are much less than from subducted sediments.

Acknowledgements We acknowledge Li-Yun Huang and Kuo-Feng Huang for $\mathrm{Sr}$ and $\mathrm{Nd}$ isotope analyses, Yi-Jen Lai for trace element analysis and Shu-Ya Hsu for electron microprobe analysis. Special thanks to Michael Rhodes and Eiichi Takazawa for the access to their XRF facilities. We also thank Wei-Min Chen and Tiannan Yang for their assistance in sampling. Critical comments from Ching-Ying Lan and an anonymous reviewer and editorial efforts of JianCheng Lee are highly appreciated. This research is supported by the NSC grants, NSC91-2116-M-006-005 and NSC96-2116-M-006-007 to Huai-Jen Yang and NSC942116-M-006-010 to Shu-Cheng Yu.

\section{REFERENCES}

Ames, L., G. Zhou, and B. Xiong, 1996: Geochronology and isotopic character of ultrahigh-pressure metamorphism with implications for collision of the Sino-Korean and Yangtze Cratons, central China. Tectonics, 15, 472-489, doi: 10.1029/95TC02552. [Link]

Audétat, A. and H. Keppler, 2005: Solubility of rutile in subduction zone fluids, as determined by experiments in the hydrothermal diamond anvil cell. Earth Planet. Sci. Lett., 232, 393-402, doi: 10.1016/j.eps1.2005.01.028. [Link]

Becker, H., K. P. Jochum, and R. W. Carlson, 1999: Constraints from high-pressure veins in eclogites on the composition of hydrous fluids in subduction zones. Chem. Geol., 160, 291-308, doi: 10.1016/S0009-2541(99)00104-7. [Link]

Becker, H., K. P. Jochum, and R. W. Carlson, 2000: Trace element fractionation during dehydration of eclogites from high-pressure terranes and the implications for element fluxes in subduction zones. Chem. Geol., 163, 65-99, doi: 10.1016/S0009-2541(99)00071-6. [Link]

Benoit, M., M. Polvé, and G. Ceuleneer, 1996: Trace element and isotopic characterization of mafic cumulates in a fossil mantle diaper (Oman ophiolite). Chem. Geol., 134, 199214, doi: 10.1016/S0009-2541(96)00087-3. [Link]

Carswell, D. A. and S. L. Harley, 1990: Mineral barometry and thermometry. In: Carswell, D. A. (Ed.), Eclogite Facies Rocks. Blackie, Glasgow, 83-110.

Chalot-Prat, F., J. Ganne, and A. Lombard, 2003: No significant 
element transfer from the oceanic plate to the mantle wedge during subduction and exhumation of the Tethys lithosphere (Western Alps). Lithos, 69, 69-103, doi: 10.1016/ S0024-4937(03)00047-1. [Link]

Chavagnac, V. and B. M. Jahn, 1996: Coesite-bearing eclogites from the Bixiling Complex, Dabie Mountains, China: Sm-Nd ages, geochemical characteristics and tectonic implications. Chem. Geol., 133, 29-51, doi: 10.1016/S00092541(96)00068-X. [Link]

Chen, R. X., Y. F. Zheng, B. Gong, Z. F. Zhao, T. S. Gao, B. Chen, and Y. B. Wu, 2007: Origin of retrograde fluid in ultrahigh-pressure metamorphic rocks: Constraints from mineral hydrogen isotope and water content changes in eclogite-gneiss transitions in the Sulu orogen. Geochim. Cosmochim. Acta, 71, 2299-2325, doi: 10.1016/j.gca. 2007.02.012. [Link]

Claeson, D. T. and W. P. Meurer, 2004: Fractional crystallization of hydrous basaltic "arc-type" magmas and the formation of amphibole-bearing gabbroic cumulates. Contrib. Mineral. Petrol., 147, 288-304, doi: 10.1007/s00410-0030536-0. [Link]

Clarke, G. L., R. Powell, and J. A. Fitzherbert, 2006: The lawsonite paradox: A comparison of field evidence and mineral equilibria modeling. J. Metamorph. Geol., 24, 715725, doi: 10.1111/j.1525-1314.2006.00664.x. [Link]

Dempster, T. J., D. C. Hay, S. H. Gordon, and N. M. Kelly, 2008: Micro-zircon: Origin and evolution during metamorphism. J. Metamorph. Geol., 26, 499-507, doi: 10.1111/ j.1525-1314.2008.00772.x. [Link]

Eggins, S. M., J. D. Woodhead, L. P. J. Kinsley, G. E. Mortimer, P. Sylvester, M. T. McCulloch, J. M. Hergt, and M. R. Handler, 1997: A simple method for the precise determination of $\geq 40$ trace elements in geological samples by ICPMS using enriched isotope internal standardisation. Chem. Geol., 134, 311-326, doi: 10.1016/S0009-2541(96) 00100-3. [Link]

Elliott, T., 2003: Tracers of the Slab. In: Eiler, J. M. (Ed.), Inside the Subduction Factory, Washington, DC, American Geophysical Union, 23-45.

Enami, M. and A. Nagasaki, 1999: Prograde P-T path of kyanite eclogites from Junan in the Sulu ultrahigh-pressure province, eastern China. Isl. Arc, 8, 459-474, doi: 10.1046/ j.1440-1738.1999.00252.x. [Link]

Franz, L., R. L. Romer, R. Klemd, R. Schmid, R. Oberhänsli, and T. Wagner, 2001: Eclogite-facies quartz veins within metabasites of the Dabie Shan (eastern China): Pressuretemperature-time-deformation path, composition of the fluid phase and fluid flow during exhumation of high-pressure rocks. Contrib. Mineral. Petrol., 141, 322-346.

Gao, J., T. John, R. Klemd, and X. Xiong, 2007: Mobilization of Ti-Nb-Ta during subduction: Evidence from rutile-bearing dehydration segregations and veins hosted in eclogite, Tianshan, NW China. Geochim. Cosmochim. Acta, 71 , 4974-4996, doi: 10.1016/j.gca.2007.07.027. [Link]

Gladney, E. S. and I. Roelandts, 1988: 1987 compilation of working values and descriptions for 383 geostandards. Geostand. Geoanal. Res., 118, 1-158.

Green, T. H. and J. Adam, 2003: Experimentally-determined trace element characteristics of aqueous fluid from partially dehydrated mafic oceanic crust at $3.0 \mathrm{GPa}, 650$ $700^{\circ}$ C. Eur. J. Mineral., 15, 815-830, doi: 10.1127/09351221/2003/0015-0815. [Link]

Greene, A. R., S. M. DeBari, P. B. Kelemen, J. Blusztajn, and P. D. Clift, 2006: A detailed geochemical study of Island arc crust: The Talkeetna arc section, south-central Alaska. $J$. Petrol., 47, 1051-1093, doi: 10.1093/petrology/eg1002. [Link]

Hermann, J., C. Spandler, A. Hack, and A. V. Korsakov, 2006: Aqueous fluids and hydrous melts in high-pressure and ultra-high pressure rocks: Implications for element transfer in subduction zones. Lithos, 92, 399-417, doi: 10.1016/ j.lithos.2006.03.055. [Link]

Hirajima, T., A. Ishiwatari, B. Cong, R. Zhang, S. Banno, and T. Nozaka, 1990: Coesite from Mengzhong eclogite at Donghai county, northeastern Jiangsu province, China. Mineral. Mag., 54, 579-583, doi: 10.1180/minmag.1990.054.377. 07. [Link]

Holland, T. J. B., 1979: High water activities in the generation of high pressure kyanite eclogites of the Tauern Window, Austria. J. Geol., 87, 1-27, doi: 10.1086/628388. [Link]

Holland, T. J. B. and R. Powell, 1998: An internally consistent thermodynamic data set for phases of petrological interest. J. Metamorph. Geol., 16, 309-343, doi: 10.1111/j.15251314.1998.00140.x. [Link]

Hwang, S. L., P. Shen, H. T. Chu, and T. F. Yui, 2000: Nanometer-size $\alpha-\mathrm{PbO}_{2}$-type $\mathrm{TiO}_{2}$ in garnet: A thermobarometer for ultrahigh-pressure metamorphism. Science, $\mathbf{2 8 8}$, 321-324, doi: 10.1126/science.288.5464.321. [Link]

Innocent, C., A. Michard, N. Malengreau, M. Loubet, Y. Noack, M. Benedetti, and B. Hamelin, 1997: Sr isotopic evidence for ion-exchange buffering in tropical laterites from the Paraná, Brazil. Chem. Geol., 136, 219-232, doi: 10.1016/S0009-2541(96)00145-3. [Link]

Jahn, B. M., 1998: Geochemical and isotopic characteristics of UHP eclogites and ultramafic rocks of the Dabie orogen: implications for continental subduction and collisional tectonics. In: Hacker, B. and J. G. Liou (Eds.), Continents Collide: Geodynamics and Geochemistry of Ultrahighpressure Rocks, Kluwer Academic Publishers, 203-239.

Jahn, B. M., 1999: Sm-Nd isotope tracer study of UHP metamorphic rocks: Implications for continental subduction and collisional tectonics. Int. Geol. Rev., 41, 859-885, doi: 10.1080/00206819909465175. [Link]

Jahn, B. M., Q. Fan, J. J. Yang, and O. Henin, 2003: Petrogenesis of the Maowu pyroxenite-eclogite body from the UHP metamorphic terrane of Dabieshan: Chemical and isotopic constraints. Lithos, 70, 243-267, doi: 10.1016/ S0024-4937(03)00101-4. [Link]

John, T. and V. Schenk, 2003: Partial eclogitisation of gabbroic rocks in a late Precambrian subduction zone (Zambia): 
Prograde metamorphism triggered by fluid infiltration. Contrib. Mineral. Petrol., 146, 174-191, doi: 10.1007/ s00410-003-0492-8. [Link]

John, T., E. E. Scherer, K. Haase, and V. Schenk, 2004: Trace element fractionation during fluid-induced eclogitization in a subduction slab: Trace element and Lu-Hf-Sm-Nd isotope systematics. Earth Planet. Sci. Lett., 227, 441-456, doi: 10.1016/j.eps1.2004.09.009. [Link]

John, T., R. Klemd, J. Gao, and C. D. Garbe-Schönberg, 2008: Trace-element mobilization in slabs due to non steadystate fluid-rock interaction: Constraints from an eclogitefacies transport vein in blueschist (Tianshan, China). Lithos, 103, 1-24, doi: 10.1016/j.lithos.2007.09.005. [Link]

Kato, T., M. Enami, and M. Zhai, 1997: Ultra-high-pressure (UHP) marble and eclogite in the Su-Lu UHP terrane, eastern China. J. Metamorph. Geol., 15, 169-182, doi: 10. 1111/j.1525-1314.1997.00013.x. [Link]

Latypov, R., S. Chistyakova, and T. Alapieti, 2007: Revisiting problem of chilled margins associated with marginal reversals in mafic-ultramafic intrusive bodies. Lithos, 99, 178206, doi: 10.1016/j.lithos.2007.05.008. [Link]

Li, S., Y. Xiao, D. Liu, Y. Chen, N. Ge, Z. Zhang, S. S. Sun, B. Cong, R. Zhang, S. R. Hart, and S. Wang, 1993: Collision of the North China and Yangtze blocks and formation of coesite-bearing eclogites: Timing and processes. Chem. Geol., 109, 89-111, doi: 10.1016/0009-2541(93)90063-O. [Link]

Li, S., E. Jagoutz, Y. Chen, and Q. Li, 2000: Sm-Nd and Rb-Sr isotopic chronology and cooling history of ultrahigh pressure metamorphic rocks and their country rocks at Shuanghe in the Dabie Mountains, central China. Geochim. Cosmochim. Acta, 64, 1077-1093, doi: 10.1016/S0016-7037(99) 00319-1. [Link]

Li, X. P., Y. F. Zheng, Y. B. Wu, F. Chen, B. Gong, and Y. L. Li, 2004: Low-T eclogite in the Dabie terrane of China: Petrological and isotopic constraints on fluid activity and radiometric dating. Contrib. Mineral. Petrol., 148, 443-470.

Ling, W., S. Gao, B. Zhang, H. Li, Y. Liu, and J. Cheng, 2003: Neoproterozoic tectonic evolution of the northwestern Yangtze craton, South China: Implications for amalgamation and break-up of the Rodinia Supercontinent. Precam. Res., 122, 111-140, doi: 10.1016/S0301-9268(02)00222X. [Link]

Liou, J. G. and R. Y. Zhang, 1996: Occurrences of intergranular coesite in ultrahigh-P rocks from the Sulu region, eastern China: Implications for lack of fluid during exhumation. Am. Mineral., 81, 1217-1221.

Lissenberg, C. J., C. R. van Staal, J. H. Bédard, and A. Zagorevski, 2005: Geochemical constraints on the origin of the Annieopsquotch ophiolite belt, Newfoundland Appalachians. GSA Bull., 117, 1413-1426, doi: 10.1130/ B25731.1. [Link]

Liu, Y. H., H. J. Yang, Y. H. Shau, F. C. Meng, J. X. Zhang, J. S. Yang, Z. Q. Xu, and S. C. Yu, 2007: Compositions of high Fe-Ti eclogites from the Sulu UHP metamorphic terrane,
China: HFSE decoupling and protolith characteristics. Chem. Geol., 239, 64-82, doi: 10.1016/j.chemgeo.2006. 12.005. [Link]

Ma, J. L., G. J. Wei, Y. G. Xu, W. G. Long, and W. D. Sun, 2007: Mobilization and re-distribution of major and trace elements during extreme weathering of basalt in Hainan Island, South China. Geochim. Cosmochim. Acta, 71, 32233237, doi: 10.1016/j.gca.2007.03.035. [Link]

Maji, A. K. and S. S. Sarkar, 2004: Quantitative genetic modeling of the Turkel anorthosite, Eastern Ghats Belt, Orissa, India. J. Asian Earth Sci., 24, 199-211, doi: 10.1016/j. jseaes.2003.10.009. [Link]

Manning, C. E., 2004: The chemistry of subduction-zone fluids. Earth Planet. Sci. Lett., 223, 1-16, doi: 10.1016/j.epsl. 2004.04.030. [Link]

Markl, G., 2001: REE constraints on fractionation processes of massive-type anorthosites on the Lofoten Island, Norway. Mineral. Petrol., 72, 325-351, doi: 10.1007/s007100170 022. [Link]

Mathison, C. I. and P. R., Hamlyn, 1987: The McIntosh layered troctolite-olivine gabbro intrusion, East Kimberly, western Australia. J. Petrol., 28, 211-234.

Miller, C., A. Zanetti, M. Thöni, and J. Konzett, 2007: Eclogitisation of gabbroic rocks: Redistribution of trace elements and $\mathrm{Zr}$ in rutile thermometry in an Eo-Alpine subduction zone (Eastern Alps). Chem. Geol., 239, 96-123, doi: 10.1016/j.chemgeo.2007.01.001. [Link]

Mitchell, J. N., J. S. Scoates, and C. D. Frost, 1995: High-AI gabbros in the Laramie Anorthosite Complex, Wyoming: Implications for the composition of melts parental to Proterozoic anorthosite. Contrib. Mineral. Petrol., 119, 166180, doi: 10.1007/BF00307279. [Link]

Plank, T. and C. H. Langmuir, 1993: Tracing trace-elements from sediment input to volcanic output at subduction zones. Nature, 362, 739-743, doi: 10.1038/362739a0. [Link]

Ravna, E. K., 2000: The garnet-clinopyroxene $\mathrm{Fe}^{2+}-\mathrm{Mg}$ geothermometer: An update calibration. J. Metamorph. Geol., 18, 211-219, doi: 10.1046/j.1525-1314.2000.00247.x. [Link]

Ravna, E. J. K. and M. P. Terry, 2004: Geothermobarometry of UHP and HP eclogites and schists - An evaluation of equilibria among garnet-clinopyroxene-kyanite-phengite-coesite/quartz. J. Metamorph. Geol., 22, 579-592, doi: 10. 1111/j.1525-1314.2004.00534.x. [Link]

Rubatto, D. and J. Hermann, 2003: Zircon formation during fluid circulation in eclogites (Monviso, Western Alps): Implications for $\mathrm{Zr}$ and $\mathrm{Hf}$ budget in subduction zones. Geochim. Cosmochim. Acta, 67, 2173-2187, doi: 10.1016/ S0016-7037(02)01321-2. [Link]

Sassi, R., C. Mazzoli, C. Miller, and J. Konzett, 2004: Geochemistry and metamorphic evolution of the Pohorje Mountain eclogites from the easternmost Austroalpine basement of the Eastern Alps (Northern Slovenia). Lithos, 78, 235-261, doi: 10.1016/j.lithos.2004.05.002. [Link]

Sheng, Y. M., Q. K. Xia, L. Dallai, X. Z. Yang, and Y. T. Hao, 
2007: $\mathrm{H}_{2} \mathrm{O}$ contents and $\mathrm{D} / \mathrm{H}$ ratios of nominally anhydrous minerals from ultrahigh-pressure eclogites of the Dabie orogen, eastern China. Geochim. Cosmochim. Actaa, 71, 2079-2103, doi: 10.1016/j.gca.2007.01.018. [Link]

Sisson, T. W., T. L. Grove, and D. S. Coleman, 1996: Hornblende gabbro sill complex at Onion Valley, California, and a mixing origin for the Sierra Nevada batholith. Contrib. Mineral. Petrol., 126, 81-108, doi: 10.1007/ s004100050237. [Link]

Spandler, C. and J. Hermann, 2006: High-pressure veins in eclogite from New Caledonia and their significance for fluid migration in subduction zones. Lithos, 89, 135-153, doi: 10.1016/j.lithos.2005.12.003. [Link]

Spandler, C., J. Hermann, R. Arculus, and J. Mavrogenes, 2003: Redistribution of trace elements during prograde metamorphism from lawsonite blueschist to eclogite facies; Implications for deep subduction-zone processes. Contrib. Mineral. Petrol., 146, 205-222, doi: 10.1007/s00410-0030495-5. [Link]

Sun, S. S. and W. F. McDonough, 1989: Chemical and isotope systematics of oceanic basalts: Implications for mantle composition and processes. In: Saunders, A. D. and M. J. Norry (Eds.), Magmatism in the Oceanic Basins, Geological Society, London, 313-345.

Turner, S. P., 1996: Petrogenesis of the late-Delamerian gabbroic complex at Black Hill, South Australia: Implications for convective thinning of the lithospheric mantle. $\mathrm{Mi}$ neral. Petrol., 56, 51-89, doi: 10.1007/BF01162657. [Link]

Wayte, G. J., R. H. Worden, D. C. Rubie, and G. T. R. Droop, 1989: A TEM study of disequilibrium plagioclase breakdown at high pressure: The role of infiltrating fluid. Contrib. Mineral. Petrol., 101, 426-437, doi: 10.1007/BF 00372216. [Link]

Williams, I. S., I. S. Buick, and I. Cartwright, 1996: An extended episode of early Mesoproterozoic fluid flow in the Reynolds Range, central Australia. J. Metamorph. Geol., 14, 29-47, doi: 10.1111/j.1525-1314.1996.00029.x. [Link]

Wilson, S. A., 1997: Data compilation for USGS reference material BHVO-2, Hawaiian Basalt, US Geological Survey Open-File Report.
Ye, K., B. Cong, and D. Ye, 2000: The possible subduction of continental material to depths greater than $200 \mathrm{~km}$. Nature, 407, 734-736, doi: 10.1038/35037566. [Link]

Zhang, R. Y., T. Hirajima, S. Banno, B. Cong, and J. G. Liou, 1995: Petrology of ultrahigh-pressure rocks from the southern Su-Lu region, eastern China. J. Metamorph. Geol., 13, 659-675, doi: 10.1111/j.1525-1314.1995.tb00250.x. [Link]

Zhang, Z., Y. Xiao, J. Hoefs, J. G. Liou, and K. Simon, 2006: Ultrahigh pressure metamorphic rocks from the Chinese continental scientific drilling project: I. Petrology and geochemistry of the main hole (0-2050 m). Contrib. Mineral. Petrol., 152, 421-441, doi: 10.1007/s00410-006-0120-5. [Link]

Zhang, Z. M., K. Shen, W. D. Sun, Y. S. Liu, J. G. Liou, C. Shi, and J. L. Wang, 2008: Fluids in deeply subducted continental crust: Petrology, mineral chemistry and fluid inclusion of UHP metamorphic veins from the Sulu orogen, eastern China. Geochim. Cosmochim. Acta, 72, 3200-3228, doi: 10.1016/j.gca.2008.04.014. [Link]

Zhao, Z. F., Y. F. Zheng, R. X. Chen, Q. X. Xia, and Y. B. Wu, 2007: Element mobility in mafic and felsic ultrahigh-pressure metamorphic rocks during continental collision. Geochim. Cosmochim. Acta, 71, 5244-5266, doi: 10.1016/j. gca.2007.09.009. [Link]

Zheng, Y. F., B. Fu, B. Gong, and L. Li, 2003: Stable isotope geochemistry of ultrahigh pressure metamorphic rocks from the Dabie-Sulu orogen in China: Implications for geodynamics and fluid regime. Earth Sci. Rev., 62, 105161, doi: 10.1016/S0012-8252(02)00133-2. [Link]

Zhou, M. F., A. K. Kennedy, M. Sun, J. Malpas, and M. Lesher, 2002: Neoproterozoic arc-related mafic intrusions along the northern margin of south China: Implications for the accretion of Rodinia. J. Geol., 110, 611-618, doi: 10.1086/ 341762. [Link]

Zhou, M. F., Y. Ma, D. P. Yan, X. Xia, J. H. Zhao, and M. Sun, 2006: The Yanbian terrane (southern Sichuan province, SW China): A Neoproterozoic arc assemblage in the western margin of the Yangtze Block. Precam. Res., 144, 19-38, doi: 10.1016/j.precamres.2005.11.002. [Link] 